\title{
Gender, culture and STEM: Counter-intuitive patterns in Arab society*
}

\author{
Naomi Friedman-Sokuler ${ }^{\dagger}$ and Moshe Justman
}

November 28, 2018

\begin{abstract}
Arab society in Israel offers a counter-example, which calls into question the hypothesis that the male advantage in STEM decreases as gender equality in society increases. Analyzing administrative longitudinal data on students in Hebrew- and Arabic-language schools in Israel, all operating within the same centralized education system, we find that the gender achievement-gap favoring girls in Arabic schools, the ethnic group characterized by less gender equality, is greater than the gender gap favoring girls in Hebrew schools. Moreover, maledominated STEM matriculation electives in Hebrew schools are female-dominated in Arabic schools, controlling for prior achievement in mathematics. We show that these patterns are not dependent on socioeconomic or school characteristics but rather reflect ethnic differences in the gendered effect of prior achievement on subject choice. While in Hebrew-language schools the gender gaps favoring men in physics, computer science and advanced mathematics electives increase in early mathematical achievement, in Arabic-language schools gender gaps favoring men are non-existent and even reversed among top achieving students.
\end{abstract}

Keywords: culture, gender gap in mathematics, STEM, Arab society, educational choice

JEL Classification Numbers: I21, J15, J16, J24.

${ }^{*}$ We gratefully acknowledge the financial support of the Rothschild Caesarea Foundation, and the technical support of the Central Bureau of Statistics, and especially Yaffa Shif, Edna Shimoni and David Gordon, in preparing the data and making it available to us. We thank Amal Abu-Tayeh, Ola Hallaq and participants at the annual meetings of the Israeli Economic Association; the American Educational Research Association and the World Educational Research Association; INET's Young Scholars Initiative Plenary; the Melbourne Institute for Applied Economic and Social research; the InGRID summer school; the CDED workshop in Groningen; EALE 2017; and the annual meetings of the Economics of Education Association for their helpful comments and suggestions. None are responsible for any of our findings or conclusions.

${ }^{\dagger}$ Department of Economics, Bar Ilan University, Israel; corresponding author, friedmn6@biu.ac.il

${ }_{\ddagger}^{\ddagger}$ Department of Economics, Ben Gurion University, Israel and Ruppin Academic Center; justman@bgu.ac.il 


\section{Introduction}

Gender roles in society are culturally conditioned, yet the way in which culture shapes gender roles may be difficult to anticipate. There is a widely observed pattern in advanced industrialized countries, of men dominating mathematically intensive occupations in the workforce, particularly engineering and information technology (Blau and Kahn, 2017). Further evidence shows that these patterns emerge yet earlier, with male students dominating mathematically intensive study fields—-such as physics and computer science—in secondary and tertiary education (Turner and Bowen, 1999, Riegle-Crumb et al., 2012; Buser et al., 2014; Friedman-Sokuler and Justman, 2016; Justman and Méndez, 2018; Rapoport and Thibout, 2018). Among industrialized countries, cross-country analysis indicates that the male advantage in mathematical achievement in secondary education decreases with general measures of gender equality in society (Guiso et al., 2008; Nollenberger et al., 2016). However, Fryer and Levitt (2010) have shown that this pattern disappears when the analysis includes predominantly Muslim countries characterized by low levels of gender equality.

The case of Arab women in Israel, which we consider here, presents an opportunity to investigate the sources of this puzzle within a unique institutional setting. Arab society in Israel, as in other Middle Eastern countries, is still characterized by distinctively low gender equality, compared to the Hebrew-speaking majority, by all measures (Abu-Baker and Azaiza, 2010; Yashiv and Kasir, 2011). Yet, as we show in this paper, students in Arabic-language schools, the ethnic group characterized by less gender equality, exhibit gender pattens favoring women, with respect to STEM achievement and choice, compared to students in Hebrew-language schools, though both types of school are governed by the same centralized Ministry of Education.

Using a longitudinal administrative data set, we follow two half-cohorts of Israeli youth attending Arabic-language and Hebrew-language schools, from the eighth grade, when they sit for standardized tests in mathematics, reading, science and English, to the twelfth-grade, when they are tested in matriculation electives chosen during the three years of high school. We find that while students in Hebrew-language schools follow similar patterns to those found in advanced industri- 
alized countries, students in Arabic-language schools exhibit a larger female advantage in mathematics, even after controlling for differences in socio-economic background. Moreover, Arab women have a greater relative propensity to choose traditionally male-dominated STEM matriculation electives_-physics, computer science and advanced mathematics—where Hebrew speaking women are very much underrepresented. This reversal is anticipated to some extent by the substantial female advantage in mathematics achievement in Arabic-language middle schools, but it is qualitatively robust to the inclusion of prior test scores and background characteristics. Finally, while in Hebrew-language schools the gender gaps favoring men in physics, computer science and advanced mathematics electives increase in early mathematical achievement, in Arabic-language schools gender gaps favoring men are non-existent and even reversed among top achieving students.

Our empirical approach is informed by the epidemiological method used by Fernández and Fogli (2009) and Nollenberger et al. (2016), to identify the effect of culture on outcomes by comparing individuals from different cultural backgrounds acting within the same institutional setting.1] While the two ethnic groups study in different schools—-segregated by language — they share the same institutional setting. The schools in our data set-both Hebrew- and Arabic-language schools-are coeducational. ${ }^{2}$ and they operate under the supervision of a single, centralized ministry of education, with similar spending per student, following the same curriculum in STEM subjects, and taking the same matriculation tests (except for translation). Their teachers belong to the same union, study at the same universities and most attend the same teacher training programs $]^{3}$ These institutional constraints suggest that the remaining differences between Hebrewand Arabic-language schools stem from different cultural norms.

These finding contribute to the existing literature in several ways. First, the experience of Arab women in Israel belies the notion of a general female disadvantage in mathematics, or of a gen-

\footnotetext{
${ }_{1}^{1}$ Fernández and Fogli (2009) use country of origin of immigrants as their cultural indicator. We follow Sutter et al. (2018) and Bargain et al. (2012) in using language, which loosely corresponds to religion, as our cultural indicator

${ }^{2}$ We exclude from this analysis Hebrew religious and ultra-orthodox schools, the overwhelming majority of which are segregated by gender. For a comparison of Hebrew religious and non-religious schools see Friedman-Sokuler and Justman (2016)

${ }^{3}$ This holds for high school teachers, which are the relevant teachers for this study.
} 
eral female aversion to STEM subjects such as physics and computer science (Ceci et al., 2014), highlighting instead the role of culture in shaping the gendered patterns of education achievement and choice. Thus our findings align with and elaborate the pattern that Fryer and Levitt (2010) revealed: an inverse relation between traditional measures of gender equality, such as female labor force participation, and gender gaps in mathematical achievement, which we extend to the choice of STEM matriculation electives. In addition, most of the quantitative analysis on the emergence of gender gaps in educational achievement and choice applies to western cultural groups in developed countries, where cultural variation is limited to the normative framework of western culture. The unique context of Israeli society offers the opportunity to compare western cultural norms to traditional-patriarchal norms, while holding the institutional setting fixed; and our longitudinal data allow us to make the comparisons while controlling for early achievement within large population cohorts.

Interestingly, this pattern does not follow through to subsequent stages: Arab women are currently as much under-represented in engineering programs in tertiary education, and in engineering and IT occupations in the workforce, as Hebrew-speaking women. This indicates that these differences are not motivated by a greater availability of jobs in STEM occupations for Arab women, though this may change as the supply of qualified Arab women grows, and there is greater demand for STEM capabilities. Quantitative and qualitative research in behavioral science suggests a number of specific channels through which culture affects the educational subject choices of Arab women, including their value in the marriage market, and differences between Arab and Western culture in the gender stereotyping of mathematically-intensive occupations. Thus, our analysis contributes to the understanding of gender gaps in the Arab world and among immigrants from these regions, highlighting the potential for increasing the participation of women in mathematically intensive fields in these societies.

The remainder of the paper proceeds as follows: Section 2 describes the Israeli context. Section 3 describes the student population and the construction of the study sample. Section 4 presents the main educational outcomes, and the unconditional ethnic and gender gaps. Section 5 outlines 
our estimation strategy, and analyses the evolution of gender gaps in achievement from eighth to twelfth grade and the choice of STEM matriculation electives. Section 6 analyzes gender and ethnic heterogeneity in the relationship between prior achievement and choice. Section 7 discusses potential mechanisms driving the ethnic differences in gender gaps. Section 8 concludes.

\section{The Israeli context}

The population of Israel comprises two major ethnic groups, with limited contact between them: Jews, accounting for $74.9 \%$ of the population, and Arabs, accounting for $20.7 \% .^{4}$ The Arab minority is predominantly Muslim (83\%), with the rest Christian and Druze, in equal proportions (Central Bureau of Statistics, 2015). The Arab minority resides overwhelmingly in distinct geographical localities, and the small percentage who live in multi-ethnic cities mostly live in segregated neighborhoods. The two ethnic groups are linguistically distinct, Jews and non-Arab Christians speak Hebrew whereas Muslims, Arab Christians and Druze are native Arabic speakers. Overall, Hebrew speakers are characterized by substantially higher average income and education levels than the Arab population (Gharrah, 2015).

Hebrew speaking society in Israel is generally characterized as Western-democratic, where Arab society is more traditional and patriarchal-hierarchical (Oyserman, 1993; Dwairy, 1997; Fogiel-Bijaoui, 2002; Cinamon, 2009). Jewish men and women, the large majority of Hebrewspeakers, share the role of wage earners and caretakers of the home and family to a greater extent than in Arab society, which defines women as dependent, as belonging to particular men, and as nurturers and caretakers of both their husbands and children Abu-Baker, 1998; Kalekin-Fishman, 2004; Cinamon, 2009). In line with this, Arab sons are raised to be the future breadwinners, where daughters are generally expected to continue the traditional roles of their mothers. Arab girls' freedom of movement is generally limited to the home or the family enclave where they are under direct supervision (Dwairy, 2004).

\footnotetext{
${ }^{4}$ The remaining $4.4 \%$ are non-Arab Christians, individuals with unclassified religion and others. These groups generally live and study as part of the Jewish majority.
} 
These cultural differences are reflected in a variety of indicators regarding gender roles $[$ Age at first marriage is highest among Jews, 25.9, and lowest among Muslims, 21.7 years. In 2013, 7.5\% of Jewish women were married by the age of 19, compared to $12.3 \%$ of Muslim women (Central Bureau of Statistics, 2015; Gharrah, 2015). The average age of mothers at first birth follows a similar pattern (Central Bureau of Statistics, 2015). When comparing labor-force participation in the prime working-age group, aged 25-54, Jewish men and women are nearly identical, $87.9 \%$ and 87.7\% respectively, whereas in the Arab population the male rate is more than twice the female rate, $81.8 \%$ versus $38.4 \%$ (Central Bureau of Statistics, 2015). With regard to political representation, in $2015,27 \%$ of Jewish members of parliament were women, compared to $12.5 \%$ among Arab members of parliament; and in municipal government women constitute $14.7 \%$ of council members in Jewish municipalities, while in Arab municipalities women account for less than $1 \%$ of council members.

Both language sectors are served by a common, centralized education system administered by a national Ministry of Education, with regard to budget, curriculum, structure, teacher supervision and labor relations. ${ }^{6}$ Virtually all Arabic-language school are co-educational (Shir. 2014), as are all non-religious Hebrew-language schools, on which we focus in this paper [7 In the past, Arabic-language schools received substantially less financial and material resources than Hebrewlanguage schools, but this gap has narrowed in recent years (Lavy, 1998; Blass et al., 2010; Justman, 2014), stemming both from the political marginalization of Arabs in Israel and from the difficulty Arabic-language schools have in obtaining funds from supplemental sources such as local councils, community institutions, non-profit organizations, and philanthropic foundations (Benavot and Resh, 2003).

In primary and secondary school, the two ethnic groups attend separate schools that teach in

\footnotetext{
${ }^{5} \mathrm{Cf}$. United Nations Economic Commission for Europe (2015).

${ }^{6}$ In 2011, the OECD estimated that 50\% of all decisions in lower secondary schools in Israel were made at the ministry level, compared to an average of 36\% among OECD countries (OECD, 2016)

${ }^{7}$ There are three types of Hebrew-language schools: state (69\%), state-religious (17\%) and ultra-orthodox (14\%) (Central Bureau of Statistics, 2003). The latter two are characterized by single sex classrooms or schools and are therefore not included in our analysis. In general, Jewish parents choose the type of school their children attend according to their religious orientation.
} 
different languages_-Hebrew and Arabic_-but follow the same curriculum in mathematics, science and English 8 There are curricular differences between Hebrew and Arabic schools in history and literature, but the most substantial difference is in the language curriculum.9 ${ }^{9}$ In the final years of secondary school, students in both Hebrew- and Arabic-language schools take the national matriculation exams. Full matriculation, a prerequisite for university admissions, requires a passing score in seven basic-level mandatory subjects, and in at least one advanced-level elective. Levels of difficulty are expressed as numbers of units studied in a subject, generally between one and five; an advanced-level elective is an elective taken at the level of five units. ${ }^{10}$ Israeli high schools have some autonomy in choosing the matriculation elective subjects they offer, in accordance with demand and the availability of qualified teachers.

\section{The data; background variables}

The sources of data for our analysis are two administrative data sets managed by the Israel Ministry of Education: the universe of students enrolled in the eighth grade in two consecutive school years, 2001/2 and 2002/3 (we refer to them in what follows as 2002 and 2003); and matriculation records of students enrolled in the twelfth grade in 2005/6 and 2006/7. These two sets were linked for our study by Israel's Central Bureau of Statistics using national Identity Numbers. The fundamental ethno-linguistic distinction in this analysis is based on school affiliation in eighth grade-attendance at a Hebrew-language or Arabic-language school ${ }^{11}$ Among Hebrew-language schools, we consider only state non-religious schools, almost all of which are co-educational, ex-

\footnotetext{
${ }^{8}$ There are seven bilingual schools in Israel, in which Jews and Arabs study together in both languages. Six of the seven schools are elementary schools, up to sixth grade. The seventh continues through high school and belongs administratively to the Hebrew-language sector.

${ }^{9}$ In Arabic schools, the first language is Arabic; in third grade students begin learning Hebrew as a mandatory second language; and in fourth grade they begin studying English as a mandatory third language. In Hebrew-language schools, English is taught as a mandatory second language starting in the fourth grade and Arabic is optional as a third language from fifth grade.

${ }^{10}$ There are over 50 electives available to students, in the natural and exact sciences, social sciences, additional foreign languages (mainly Arabic for Hebrew-speakers and French), geography, art and others.

${ }^{11}$ The data we use also records students' religion as recorded in the population registry. Among Jewish students, 0.06\% attended eight grade in an Arabic language school; among Muslim, Arab-Christian and Druze students, 1.01\% attended a Hebrew-language school.
} 
cluding from our analysis gender-segregated Jewish ultra-orthodox and state religious schools, so as to avoid the confounding influence of single-sex education.12 Arabic language schools are almost all coeducational (Shir, 2014).13

Our full population comprises 166,269 students, two cohorts of students enrolled in eighth grade in Arabic- and Hebrew-language state schools during the school years 2002 and 2003, of whom 51.7\% were male, and 26.7\% attended Arabic language schools (Table 11). In the eighth grade, we observe for these students: parents' years of education, school attended by the student and its characteristics, municipality of residence, and country of birth. In 2002 and 2003 the ministry of education implemented the Growth and Efficiency Measures in Schools (GEMS) standardized testing scheme. All publicly funded schools in Israel with an eighth grade, except Jewish ultra-orthodox schools and special education schools, were split into two balanced samples of equal size, with half the schools participating in GEMS in 2002 and the other half in 2003. For students who took at least one of the four GEMS tests we also observe the family income quintile 14 We also observe for all students in both cohorts who attended twelfth grade four years after attending eighth grade (in 2006 and 2007, respectively): the school they attend in the twelfth grade, eligibility for a matriculation certificate, level of difficulty of each mandatory subject, science electives chosen and their level of difficulty, and scores in the different matriculation tests ${ }^{15}$

Our measures of eighth-grade achievement are individual scores in the four GEMS tests: Reading (native language skills in Hebrew/Arabic), Mathematics, English, and Science and Technology. Half of the schools were tested in 2002 and the other half in 2003. We refer to the students enrolled in these schools as the GEMS sample. It includes 85,012 students of whom 51.5\% are male and 25.5\% attend Arabic-language schools. The drop in the share of Arab students, compared to the

\footnotetext{
${ }^{12}$ We also do not include special education schools. Differences in gender streaming patterns between Jewish state and state-religious schools are analyzed in Feniger (2010) and Friedman-Sokuler and Justman (2016).

${ }^{13}$ In our study sample, $4 \%$ of students in Arabic-language schools and $2 \%$ of students in Hebrew-language schools attend single-sex schools. We include them in our sample to avoid selection; omitting these students has no effect on our results.

${ }^{14}$ Family income is the gross income of both parents as reported to the Israel Tax Authority. Income quintiles were defined over the population of students participating in GEMS in 2002 and 2003.

${ }^{15} \mathrm{We}$ observe matriculation outcomes only for students who enrolled in the twelfth grade four years after attending eighth grade. In Israel, repeating or skipping a grade in secondary school is rare. Students migrating to Israel between the eighth and twelfth grades are excluded from our study.
} 
full population, is due to the fact that some of the Arabic Church schools, attended by about $4 \%$ of the Arab student population, did not participate in the first years of the GEMS assessment but appear in our full population $\sqrt{16}$ Table 1 shows that for students attending Hebrew-language schools, differences in parental education between the full population and the GEMS sample are negligible, while in Arabic schools, the average levels of parental education are slightly lower in the GEMS sample. This decline is because the Arabic Church schools that did not participate in these waves of GEMS enroll children from families with above-average education and income. For students in our full population who attended twelfth grade four years after eighth grade we observe twelfth grade outcomes, but not eighth grade scores. In Appendix A1, we analyze the effect of attrition on female-to-male achievement and choice ratios in twelfth-grade, and find that it has little effect.

Finally, to obtain the study sample, we also drop students enrolled in GEMS schools for whom we have no data on parental education or fewer than two of the four GEMS scores $\sqrt{17}$ Over a third of students in Hebrew schools in the GEMS sample, and nearly a quarter of students in Arabic schools, have only two or three GEMS scores (see Table A2 in the Appendix), and for these we impute the missing scores from the scores we have and from student background variables, separately for Hebrew and Arabic schools ${ }^{18}$ Where we have both parents' years of education, we use the larger value as our explanatory variable; where we have education for only one parent we use that value. This leaves us with a study sample of 68,050 students of whom $50.3 \%$ are male and $24.2 \%$ attended Arabic-language schools. Comparing the GEMS sample to the study sample we see that there is attrition at the lower end of the socio-economic distribution for both Arabs and Jews and more so for boys in each language sector. Consequently GEMS scores are

\footnotetext{
${ }^{16}$ The Arabic Church schools are considered elite schools in Arab society in Israel. They are fee-paying schools, owned by various churches and partially funded by the Ministry of Education. These schools are attended by both Christians and Muslims. The average share of Christian students in Arabic-language schools that did not participate in either wave of GEMS is 39\%, compared to $12 \%$ in all Arabic-language schools.

${ }^{17}$ Table A2 in the Appendix shows attrition patterns from the GEMS sample to the study sample. We drop $15 \%$ of the GEMS sample for whom we have less than two GEMS scores, and an additional $9 \%$ of the sample for missing family background.

${ }^{18}$ We impute missing GEMS scores by regressing each GEMS score on the other scores and on all available background characteristics for students with all scores, and use the regression to predict missing scores. Adding school fixed effects made very little difference to the imputed values. Qualitatively, our results are robust to limiting the sample to students with all four GEMS score.
} 


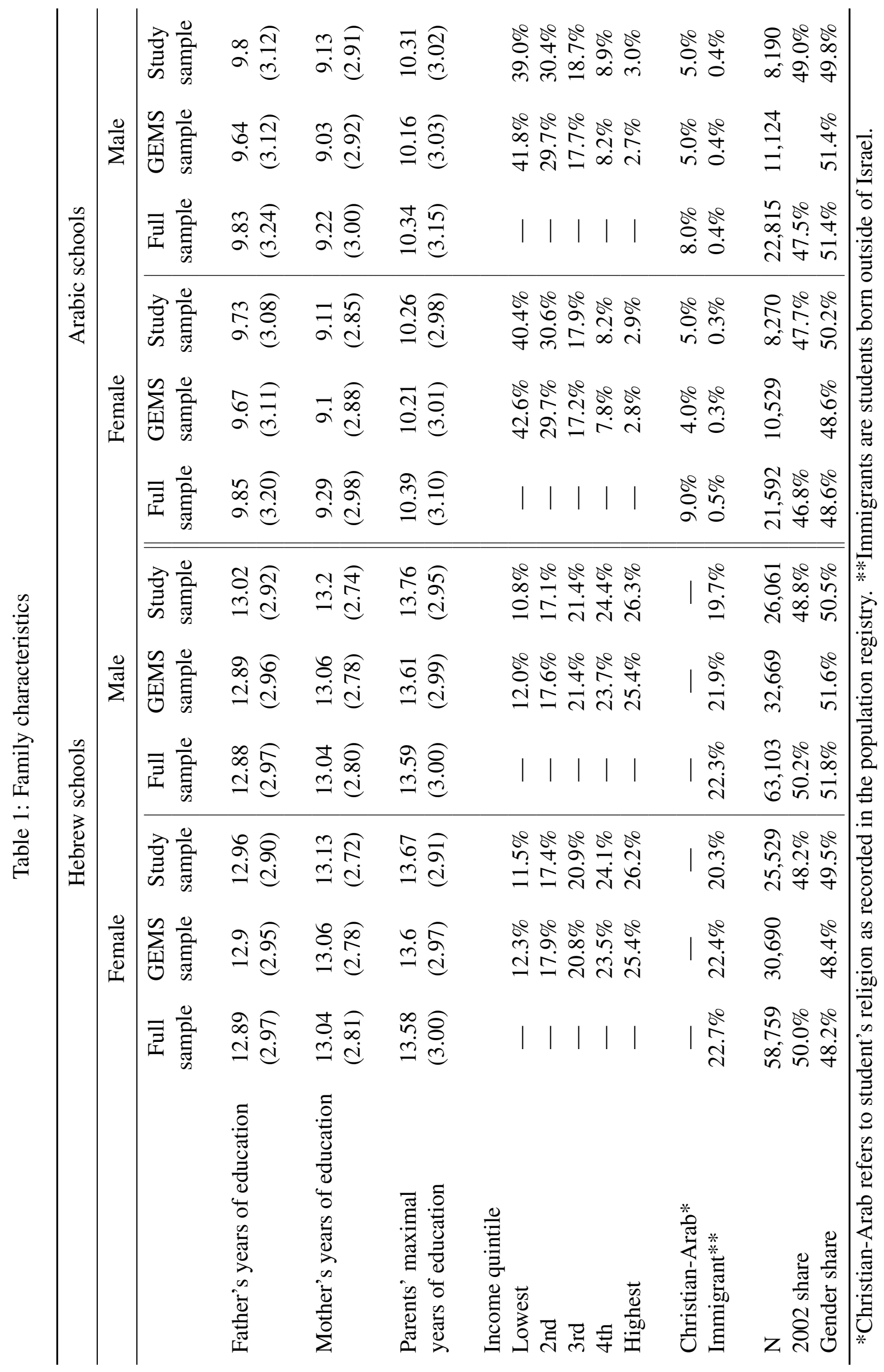


slightly lower in the GEMS sample than in the study sample, with differences ranging from 0.02 standard deviations for girls in Hebrew-language schools to 0.06 standard deviations for boys in Arabic-language schools (Appendix Table A2).

In each of the three groups in Table 1 the full population, the GEMS sample and the study sample-the two ethnic groups are socio-economically distinct. Parents of students in Hebrew schools have, on average, three more years of schooling than parents of students in Arabic schools. Moreover, while in Hebrew-language schools mothers are slightly more educated than fathers, the opposite is true in Arabic-language schools. In terms of family income, the differences are even starker. Only $10 \%$ of students in Arabic schools are in the top two income quintiles, compared to half of the students in Hebrew schools. When moving from the GEMS sample to the study sample, we see that among both Hebrew- and Arabic-language students, boys' socio-economic status (SES) improves more than girls' SES. This is due to the fact that boys are more likely to have fewer than two GEMS scores (see Table A2 in the appendix), an indicator for absenteeism that is highly correlated with SES. Consequently in both ethnic groups, the difference between boys' and girls' SES is slightly larger in the study sample.

\section{Outcome measures}

The two language sectors also differ substantially in the educational outcomes we analyze here: eighth-grade test scores and end-of-high-school attainment and choice of matriculation electives. Table 2 presents eighth-grade achievement levels by ethnicity and gender. In all eighth-grade subjects, the ethnic gaps in favour of Hebrew schools are sizeable, ranging from 0.46 of a standard deviation in science to 0.79 in English 19 Table A2 in the Appendix shows that the gender-ethnic gaps in the study sample are nearly identical to those of the full GEMS sample. In both ethnic groups, girls outperform boys, and to a larger extent in the language arts-native language and English. However, the gaps are larger in Arabic-language schools, especially in mathematics and

\footnotetext{
${ }^{19}$ The larger gap in English is a result of English being a third language in Arabic schools (Hebrew is the second), where it is the second language in Hebrew schools.
} 
science, where Arab girls outperform boys by 0.26 and 0.34 of a standard deviation respectively, compared to 0.07 and 0.04 of a standard deviation in Hebrew-language schools. These findings accord with the previous cross-sectional findings of Birenbaum and Nasser (2006), Birenbaum et al. (2007) and Rapp (2015), indicating an advantage in mathematics for Hebrew-language schools and for girls, with a larger advantage for girls in Arabic-language schools.

Table 2: Eighth grade scores in GEMS (standard deviations in parentheses)

\begin{tabular}{lccc||ccc}
\hline & \multicolumn{3}{c}{ Hebrew schools } & \multicolumn{3}{c}{ Arabic schools } \\
& Female & Male & Gender & Female & Male & Gender \\
& & & gap* & & & \\
gap*
\end{tabular}

At the end of high school, Arab students have significantly weaker outcomes, on average, than Hebrew-language students; and Arab boys have significantly weaker outcomes than all other groups. The top panel of Table 3 shows that Arab boys drop out at a substantially higher rate than any other group. In both language sectors, girls are more likely to matriculate than boys in their group but the gaps are much wider in Arabic schools. These gaps change markedly with respect to the share of students choosing matriculation electives in science. As Table 3 shows, Arab students choose science electives at a higher rate than students in Hebrew-language schools. 
Moreover, where girls in Hebrew-language schools are less likely to choose a science or mathematics elective than boys, this is not the case in Arabic-language schools. Almost two thirds of girls and over half the boys in Hebrew-language schools matriculate without taking any science elective, where in Arabic language schools the shares of girls and boys who matriculate without taking a science elective are similar, and both are under 30\%. Moreover, there are substantial differences between language sectors in the choice of specific science electives. The share of students choosing advanced mathematics and computer science is substantially higher in Hebrew-language schools where in Arabic-language schools a larger share choose biology and chemistry.

Table 3: Twelfth grade attainment and choice

\begin{tabular}{|c|c|c|c|c|c|c|}
\hline & \multicolumn{3}{|c|}{ Hebrew schools } & \multicolumn{3}{|c|}{ Arabic schools } \\
\hline & Female & Male & $\begin{array}{r}\text { Gender } \\
\text { gap* }\end{array}$ & Female & Male & $\begin{array}{r}\text { Gender } \\
\text { gap* }\end{array}$ \\
\hline Reached the twelfth grade & 0.94 & 0.89 & 0.05 & 0.92 & 0.76 & 0.16 \\
\hline Matriculation certificate & 0.67 & 0.55 & 0.12 & 0.50 & 0.28 & 0.22 \\
\hline Science elective ${ }^{* *}$ & 0.29 & 0.35 & -0.07 & 0.60 & 0.40 & 0.19 \\
\hline Matriculation with no STEM & 0.44 & 0.29 & 0.15 & 0.14 & 0.08 & 0.05 \\
\hline as a share of those matriculating & 0.66 & 0.53 & 0.13 & 0.28 & 0.29 & -0.01 \\
\hline Physics & 0.05 & 0.13 & -0.08 & 0.08 & 0.07 & 0.01 \\
\hline Computer science & 0.04 & 0.11 & -0.07 & 0.03 & 0.20 & 0.00 \\
\hline Biology & 0.14 & 0.08 & 0.06 & 0.33 & 0.18 & 0.15 \\
\hline Chemistry & 0.08 & 0.06 & 0.02 & 0.17 & 0.08 & 0.09 \\
\hline Physics or computer science & 0.07 & 0.18 & -0.11 & 0.09 & 0.08 & 0.01 \\
\hline Biology or chemistry & 0.19 & 0.13 & 0.06 & 0.41 & 0.22 & 0.19 \\
\hline Advanced mathematics (5 units) & 0.14 & 0.16 & -0.02 & 0.12 & 0.08 & 0.04 \\
\hline
\end{tabular}

Gendered choice patterns vary markedly between the two ethnic groups. In the selection of 
physics and computer science, girls in Hebrew-language schools are under-represented at a rate of 2.6 to one, while girls in Arabic schools are slightly more likely to choose these subjects than Arab boys. In Hebrew-language schools, $16 \%$ of boys and $14 \%$ of girls choose the highest level of mathematics, 5 units, while among Arabs, girls are the majority at this level, $12 \%$ to $8 \%$. In biology and chemistry, girls are overrepresented in both sectors, and more so in Arabic schools. For the purpose of the current analysis, we pool advanced physics with advanced computer science, and advanced biology with advanced chemistry. The two subjects in each pair exhibit similar gender patterns and combining categories simplifies the presentation of our results and increases statistical power ${ }^{20}$ The raw ethnic difference in the gender gaps are 12 percentage points in physics or computer science, 13 percentage points in biology or chemistry, and 6 percentage points in adanced mathematics.

\section{Estimation}

To isolate the cultural component of the gender gaps in achievement and choice patterns, we apply a variation of the epidemiological approach used by Antecol (2000) and Fernández and Fogli (2006, 2009), and expanded in Fernández (2011), to identify cultural effects on individual choices and outcomes by comparing descendants of immigrants from different countries living in the same country. Here we apply this approach to cultural variation between two native ethnic groups differing in religion and language but studying in schools run by the same (centralized) ministry of education.

\subsection{Main specification}

Our main specification, equation (1), applies a difference-in-difference regressions to estimate the difference, $\delta$, between gender gaps in the two ethnic groups, conditional on socio-economic

\footnotetext{
${ }^{20}$ These are also the two most common combinations of electives. Most results hold qualitatively also for each elective separately. Note that selection within categories may also reflect restricted choice, as fewer schools offer chemistry or computer science than offer biology or physics. We adopted a similar approach in Friedman-Sokuler and Justman(2016).
} 
background, and in the case of twelfth-grade outcomes, conditional also on prior scores:

$$
y_{i s}=\beta_{0}+\beta_{F} \text { Female }_{i}+\beta_{A} \text { Arab }_{i}+\delta \text { Female }^{*} \text { Arab }_{i}+\mathbf{X}_{\mathbf{i}} \boldsymbol{\theta}+\mathbf{A}_{\mathbf{i}} \boldsymbol{\gamma}+\mathbf{S}_{\mathbf{s}} \boldsymbol{\lambda}+\eta_{t}+u_{i s}
$$

Here $y_{i s}$ is the educational outcome of student $i$ in school $s$, Female is an indicator for whether a student is female and Arab for whether the student attends an Arabic school in eighth grade, $\mathbf{X}_{\mathbf{i}}$ is a vector of socio-economic characteristics and $\eta_{t}$ is a year fixed effect. For twelfth grade outcomes we add a vector of the student's prior achievement, $\mathbf{A}_{\mathbf{i}}$, and in some specifications we also add school-school level characteristics, $\mathbf{S}_{\mathbf{s}}$. The error term, $u_{i s}$, is clustered at the school level. The coefficient of interest, $\delta$, estimates the difference in the female advantage between Arabic and Hebrew language schools, controlling for socio-economic characteristics and, in twelfth grade, prior achievement.

Equation 1 implicitly assumes that the effect of SES and prior achievement is homogeneous across gender. However, Friedman-Sokuler and Justman (2016) found that in Hebrew-language schools the size of the gender gap increases in parental education, and more steeply in the maledominated subjects, advanced mathematics and physics or computer science, indicating that boys benefit more from a strong family background ${ }^{21}$ The literature suggests two potential explanations for this phenomenon. The first relates to gender differences in non-cognitive skills, resulting in males having higher rates of developmental problems, disruptive behavior, attention disorders, reading disabilities, and other related phenomena which may be amplified when combined with dimensions of social disadvantage correlated with fewer years of parental education (Goldin et al. 2006; DiPrete and Jennings, 2012). In addition, as occupational segregation and the gender paygap are more pronounced in jobs that do not require post-secondary education, girls may face stronger incentives to invest in secondary education (Dwyer et al., 2013). To allow for heterogeneity in the effect of socio-economic characteristics by gender, we use equation (2) to estimate the

\footnotetext{
${ }^{21} \mathrm{We}$ also tested for differences by language sector, but this did not change the mean ethnic differences in gender gaps. Results are available upon request. In section 6 , our analysis of heterogeneity considers each of the four genderlanguage groups separately.
} 
ethnic gap separately for male and female students, where $g$ represents female or male;

$$
y_{i s}^{g}=\beta_{0}^{g}+\beta_{A}^{g} A r a b+\mathbf{X}_{\mathbf{i}} \boldsymbol{\theta}^{g}+\mathbf{A}_{\mathbf{i}} \boldsymbol{\gamma}^{g}+\mathbf{S}_{\mathbf{s}} \boldsymbol{\lambda}^{g}+\eta_{t}^{g}+u_{i s}^{g} \quad g=F, M
$$

Here $\beta_{A}^{F}-\beta_{A}^{M}$ is the counterpart of $\delta$ in equation (1): the difference in the "Arab" effect between female and male students, controlling for socio-economic characteristics and prior achievement, and allowing for differences in marginal effects by gender.

For ease of interpretation, all equations are estimated using OLS when eighth-grade scores are the dependent variables, and a linear probability model when twelfth-grade binary outcomes are the dependent variable ${ }^{22}$ We also estimated the same choice model using a multinomial logistic regression model, with "no matriculation" as the baseline outcome. This did not alter the sign or significance of our results, but we prefer the single outcome framework, as matriculation electives are not mutually exclusive.

\subsection{Ethnic differences in gender gaps in eighth-grade achievement}

The top panel of Table 4 presents coefficient estimates from equation (1) for each of the four standardized GEMS scores: $\beta_{F}$, the gender gap in Hebrew-language schools; $\beta_{A}$, the ethnic achievement gap; and $\delta$, the ethnic difference in gender gaps. ${ }^{23}$ The gender gap in Arabic language schools is substantially higher that in Hebrew-language schools, by 0.16 of a standard deviation in mathematics to a third of a standard deviation in science, and the differences are statistically significant. Conditioning estimates on socio-economic characteristics, in the even numbered columns, substantially reduces the disadvantage of Arab students in the different subjects $\left(\beta_{A}\right)$, but the ethnic differences in gender gaps remain unaltered. Adding up the three coefficients in the even-numbered columns, we find that conditional on SES, achievement of Arab girls is similar to that of boys in Hebrew-language schools in all subjects except reading, where Arab girls perform substantially

\footnotetext{
${ }^{22}$ Coefficients' signs and significance as well as predicted probabilities do not differ substantially when estimated using a logistic regression framework. Results are available upon request

${ }^{23}$ The full outputs for the four GEMS domains of Equation 1 can be found in Table A3
} 
better.

Table 4: Ethnic differences in gender gaps in eighth-grade GEMS scores, conditioned on socioeconomic indicators

\begin{tabular}{|c|c|c|c|c|c|c|c|c|}
\hline & \multicolumn{2}{|c|}{ Mathematics } & \multicolumn{2}{|c|}{ Science } & \multicolumn{2}{|c|}{ Reading } & \multicolumn{2}{|c|}{ English } \\
\hline & (1) & (2) & (1) & (2) & (1) & (2) & (1) & (2) \\
\hline & & & & erence in & ence estim & & & \\
\hline \multirow[t]{2}{*}{ Female, $\beta_{F}$} & $0.07 * * *$ & $0.08 * * *$ & $0.04 * *$ & $0.05 * * *$ & $0.38 * * *$ & $0.39 * * *$ & $0.20 * * *$ & $0.21 * * *$ \\
\hline & $(0.01)$ & $(0.01)$ & $(0.01)$ & $(0.01)$ & $(0.01)$ & $(0.01)$ & $(0.01)$ & $(0.01)$ \\
\hline \multirow{2}{*}{ Arab, $\beta_{A}$} & $-0.66 * * *$ & $-0.27 * * *$ & $-0.62 * * *$ & $-0.27 * * *$ & $-0.77 * * *$ & $-0.43 * * *$ & $-0.86 * * *$ & $-0.46 * * *$ \\
\hline & $(0.04)$ & $(0.04)$ & $(0.04)$ & $(0.04)$ & $(0.04)$ & $(0.04)$ & $(0.05)$ & $(0.05)$ \\
\hline \multirow[t]{2}{*}{ FemaleXArab, $\delta$} & $0.17 * * *$ & $0.16^{* * *} *$ & $0.34 * * *$ & $0.33 * * *$ & $0.23 * * *$ & $0.23 * * *$ & $0.18 * * *$ & $0.18 * * *$ \\
\hline & $(0.03)$ & $(0.02)$ & $(0.03)$ & $(0.02)$ & $(0.02)$ & $(0.02)$ & $(0.02)$ & $(0.02)$ \\
\hline & & & \multicolumn{4}{|c|}{ Arab coefficients, estimated by gender $\left(\beta_{A}^{g}\right)$} & & \\
\hline \multirow{3}{*}{$\begin{array}{l}\text { Among females: } \\
\beta_{A}^{F}\end{array}$} & & & & & & & & \\
\hline & $-0.49 * * *$ & $-0.13^{* *}$ & $-0.28 * * *$ & 0.04 & $-0.54 * * *$ & $-0.23 * * *$ & $-0.68 * * *$ & $-0.32 * * *$ \\
\hline & $(0.05)$ & $(0.05)$ & $(0.04)$ & $(0.04)$ & $(0.04)$ & $(0.04)$ & $(0.04)$ & $(0.04)$ \\
\hline \multirow{2}{*}{$\begin{array}{l}\text { Among males: } \\
\beta_{A}^{M}\end{array}$} & & & & & & & & \\
\hline & $\begin{array}{l}-0.66^{* * * *} \\
(0.04)\end{array}$ & $\begin{array}{l}-0.25 * * * \\
(0.04)\end{array}$ & $\begin{array}{l}-0.62 * * * * \\
(0.04)\end{array}$ & $\begin{array}{l}-0.25 * * * \\
(0.04)\end{array}$ & $\begin{array}{l}-0.77 * * * \\
(0.04)\end{array}$ & $\begin{array}{l}-0.41 * * * \\
(0.04)\end{array}$ & $\begin{array}{l}-0.86^{* * *} \\
(0.05)\end{array}$ & $\begin{array}{l}-0.42 * * * \\
(0.05)\end{array}$ \\
\hline$\beta_{A}^{F}-\beta_{A}^{M}$ & 0.17 & 0.12 & 0.34 & 0.29 & 0.23 & 0.18 & 0.18 & 0.10 \\
\hline SES controls & & $\checkmark$ & & $\checkmark$ & & $\checkmark$ & & $\checkmark$ \\
\hline Share female & & & & & & & & \\
\hline $\mathrm{N}$ & 61 , & & 60 , & 57 & 62 & 29 & & 10 \\
\hline
\end{tabular}

Notes: Dependent variables vary by vertical panel and are standardized GEMS scores. Coefficients are obtained from a linear regression model with school-level clustered standard errors and a dummy for cohort. Family SES variables include family income quintiles, parents' maximal years of schooling and immigrant status. In the bottom panel equations are estimated by gender. $\beta_{A}^{F}-\beta_{A}^{M}$ estimates ethnic differences in the gender gap when coefficients on the controls may vary by gender. Standard errors in parentheses.

$* p<0.05$ ** $p<0.01 \quad * * * p<0.001$

The bottom panel of Table 4 estimates equation (2) separately for male and female students. While in columns (1) the ethnic difference in gender gaps, $\beta_{A}^{F}-\beta_{A}^{M}$, is identical to that estimated in the top panel, $\beta_{A}^{F}-\beta_{A}^{M}$, allowing slopes to vary by gender, in columns (2), slightly reduces this estimate by 0.04 of a standard deviation in mathematics and science, and up to 0.08 of a standard deviation in English - the score increase attributed to the higher SES of Hebrew-language students is steeper among male students than among female students. This finding indicates that 
Figure 1: Gender and ethnic gaps in GEMS mathematics scores, by parents' education

(a) Female, $\beta_{F}$

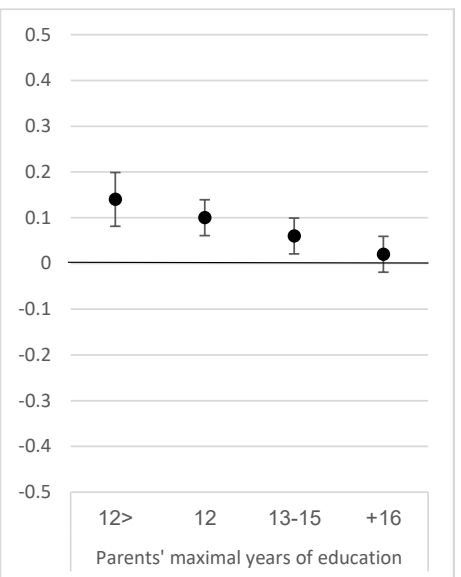

(b) Arab, $\beta_{A}$

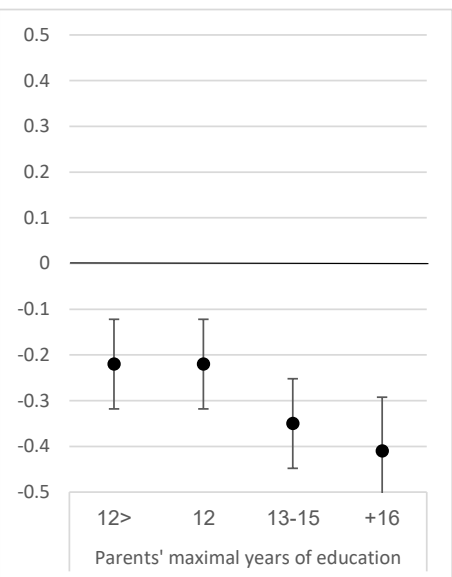

(c) Female*Arab, $\delta$

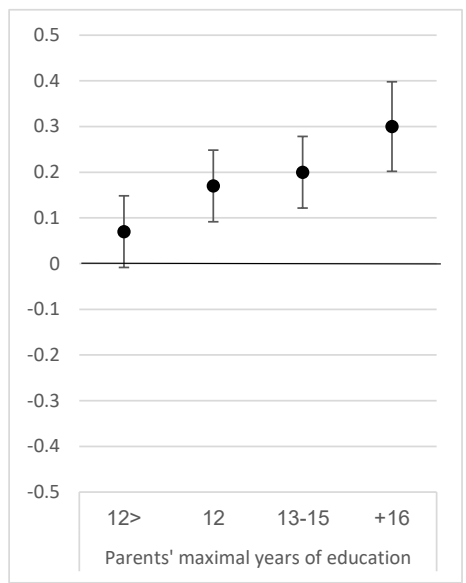

Notes: Dots represent point estimates of coefficients from Equation 1, by subsample, with $95 \%$ confidence intervals. All estimates are conditioned on family income quintiles, parents' maximal years of schooling and immigrant status. Mathematics scores are normalized to have a mean of 0 and standard deviation of 1 .

between $12 \%$ to $44 \%$ of the ethnic difference in gender gaps favoring girls in Arab schools can be attributed to Arab boys being more adversely affected by the lower socio-economic status of the Arab population than girls.

Figure 1 presents estimates of $\beta_{F}, \beta_{A}$ and $\delta$ for sub-samples defined by parents' maximal years of education, allowing us to track the change in the gender gap with parental education separately for the Arabic and Hebrew sectors. It shows that the gap favoring girls in Hebrew-language schools, $\beta_{F}$, declines with parents' education, while the gap favoring girls in Arabic-language schools, $\beta_{F}+\delta$, increases with parental education. This reflects a key cultural difference between the Arabic- and Hebrew-language sectors ${ }^{24}$

\footnotetext{
${ }^{24}$ Figure 1 can also be used to compare the ethnic gap for different levels of parental education, separately for male and female students: $\beta_{A}$, the ethnic gap among male students, increases (in absolute value) with parental education, where $\beta_{A}+\delta$, the ethnic gap among female students, shows no trend with parental education.
} 


\subsection{Ethnic differences in gender gaps in twelfth-grade attainment}

A similar picture emerges when estimating the ethnic difference in gender gaps with respect to twelfth-grade attainment measures using a linear probability model, presented in the top panel of Table $5{ }^{25}$ As columns (1) show, the raw ethnic gap is substantial: girls in both language sectors have a higher probability of reaching twelfth grade and matriculating; and the gap favoring girls in Arabic-language schools, $\delta$, is larger by about 10 percentage points than in Hebrew-language schools. Controlling for SES, in columns (2), does not alter the female advantage $\left(\beta_{F}\right)$ or the ethnic difference in the female advantage $(\delta)$, but it does reduce the overall ethnic gap $\left(\beta_{A}\right)$ by half, for retention, and by two-thirds, for matriculation rates. In columns (3) we add a second-degree polynomial of eighth-grade GEMS scores as well as an interaction term between mathematics and reading scores. Conditioned on eighth-grade scores and SES, the male retention and matriculation rates in Arabic schools are not significantly different from the corresponding rates in Hebrew-language schools, where the female rates in Arabic schools are significantly higher than in Hebrew-language schools. Gender gaps in both sectors, though reduced, remain significant after conditioning on prior scores and SES, as do the differences in the gender gap between the two language sectors. The advantage of girls over boys grows during high school in both sectors, but more so in Arabic-language schools.

Controlling only for socio-economic background, but allowing it to vary by gender, in columns (2) of the bottom panel of Table 5, shows that the difference between Hebrew- and Arabic-language students in socio-economic composition explains 40 percent of the ethnic difference in the gender gap in retention, which falls from 0.10 to 0.06 , but has little effect on the estimated difference in matriculation rates ${ }^{26}$ Allowing coefficients of both socio-economic status and prior achievement to vary by gender, in columns (3), reduces the ethnic difference in gender gaps in retention by more than half, but increases by half the estimated ethnic difference in gender gaps in matriculation rates.

\footnotetext{
${ }^{25}$ Full outputs for these regressions can be found in Table A4

${ }^{26}$ Thus the relative impact of socio-economic factors on retention differences is larger than their impact on differences in GEMS scores except for English, indicated in the bottom panel of Table 4 . The relative impact of socioeconomic factors on differences in matriculation rates is smaller than their impact on differemces in all GEMS scores.
} 
Table 5: Ethnic differences in the gender gap in twelfth-grade retention and matriculation rates, conditioned on socio-economic indicators and prior achievement

\begin{tabular}{|c|c|c|c|c|c|c|}
\hline & \multicolumn{3}{|c|}{ Twelfth-grade retention } & \multicolumn{3}{|c|}{ Matriculation } \\
\hline & (1) & (2) & (3) & (1) & (2) & (3) \\
\hline & \multicolumn{6}{|c|}{ Difference in Difference } \\
\hline Female, $\beta_{F}$ & $\begin{array}{l}0.05 * * * \\
(0.00)\end{array}$ & $\begin{array}{l}0.06 * * * \\
(0.00)\end{array}$ & $\begin{array}{l}0.04 * * * \\
(0.00)\end{array}$ & $\begin{array}{l}0.12 * * * \\
(0.01)\end{array}$ & $\begin{array}{l}0.13 * * * \\
(0.01)\end{array}$ & $\begin{array}{l}0.07 * * * \\
(0.00)\end{array}$ \\
\hline Arab, $\beta_{A}$ & $\begin{array}{l}-0.13 * * * \\
(0.03)\end{array}$ & $\begin{array}{l}-0.07 * * \\
(0.02)\end{array}$ & $\begin{array}{l}-0.02 \\
(0.02)\end{array}$ & $\begin{array}{l}-0.27 * * * \\
(0.02)\end{array}$ & $\begin{array}{l}-0.08 * * * \\
(0.02)\end{array}$ & $\begin{array}{l}0.01 \\
(0.01)\end{array}$ \\
\hline FemaleXArab, $\delta$ & $\begin{array}{l}0.11 * * * \\
(0.02)\end{array}$ & $\begin{array}{l}0.11 * * * \\
(0.02)\end{array}$ & $\begin{array}{l}0.07 * * * \\
(0.02)\end{array}$ & $\begin{array}{l}0.09 * * * \\
(0.01)\end{array}$ & $\begin{array}{l}0.09 * * * \\
(0.01)\end{array}$ & $\begin{array}{l}0.04 * * * \\
(0.01)\end{array}$ \\
\hline & \multicolumn{6}{|c|}{ Arab coefficients, estimated by gender $\left(\beta_{A}^{g}\right)$} \\
\hline $\begin{array}{l}\text { Among females: } \\
\beta_{A}^{F}\end{array}$ & $\begin{array}{l}-0.03 * \\
(0.01)\end{array}$ & $\begin{array}{l}0.02 \\
(0.01)\end{array}$ & $\begin{array}{l}0.03 * * * \\
(0.01)\end{array}$ & $\begin{array}{l}-0.17 * * * \\
(0.02)\end{array}$ & $\begin{array}{l}0.01 \\
(0.02)\end{array}$ & $\begin{array}{l}0.06 * * * \\
(0.02)\end{array}$ \\
\hline $\begin{array}{l}\text { Among males: } \\
\beta_{A}^{M}\end{array}$ & $\begin{array}{l}-0.13 * * * \\
(0.03)\end{array}$ & $\begin{array}{l}-0.04 \\
(0.02)\end{array}$ & $\begin{array}{l}0.00 \\
(0.02)\end{array}$ & $\begin{array}{l}-0.27 * * * \\
(0.02)\end{array}$ & $\begin{array}{l}-0.08 * * * \\
(0.02)\end{array}$ & $\begin{array}{l}0.00 \\
(0.01)\end{array}$ \\
\hline$\beta_{A}^{F}-\beta_{A}^{M}$ & 0.10 & 0.06 & 0.03 & 0.10 & 0.09 & 0.06 \\
\hline $\begin{array}{l}\text { SES controls } \\
\text { GEMS controls }\end{array}$ & & $\checkmark$ & $\begin{array}{l}\checkmark \\
\checkmark\end{array}$ & & $\checkmark$ & $\begin{array}{l}\checkmark \\
\checkmark\end{array}$ \\
\hline
\end{tabular}

Notes: In the top panel, $N=68,050$; in the bottom panel equations are estimates separately by gender, $N_{\text {female }}=33,799$ and $N_{\text {male }}=34,251$. Dependent variables vary by vertical panel: twelfth-grade retention; and matriculation rates. Coefficients are obtained from a LPM with school-level clustered standard errors and a dummy for cohort. In columns (2) and (3) estimates are conditioned on family income quintiles, parents' maximal years of schooling and immigrant status. In columns (3) estimates are also conditioned on a second degree orthogonalized polynomial of the four GEMS scores (mathematics, science, reading and English) as well as an interaction between the reading and mathematics percentiles. $\beta_{A}^{F}-\beta_{A}^{M}$ estimates ethnic differences in the gender gap when coefficients on the controls may vary by gender. All GEMS scores are normalized to have a mean of 0 and standard deviation of 1 . Standard errors in parentheses. * $p<0.05 * *$ $p<0.01 \quad * * * \quad p<0.001$ 
Thus high school exacerbates the relative negative effect of social disadvantage on boys' retention rates, but not on their matriculation rates.

\subsection{Ethnic differences in gender gaps in the choice of STEM electives}

In Table 6 we estimate the ethnic difference in gender gaps in the choice of advanced science and mathematics matriculation electives in our study sample, again using a linear probability model ${ }^{27}$ The top panel reveals that, as in previous outcomes, the differences between ethnic groups in the relative position of girls are persistent and statistically significant for all STEM choices, even after controlling for SES in columns (1). Conditioning choice on prior achievement in columns (2) slightly narrows the difference in gender gaps between the two language sectors, mainly due to the relatively low GEMS scores of Arab boys. After controlling for prior scores and SES, girls in Arabic-language schools are 2 percentage points less likely than boys to choose physics or computer science $\left(\beta_{F}+\delta\right)$, a difference that is not statistically significant, compared to a highly significant 12 percentage point gap in Hebrew-language schools $\left(\beta_{F}\right)$. Conditional on SES and prior achievement, there is no gender gap in advanced mathematics among Arab students while the underrepresentation of girls in Hebrew-language schools persists. Girls in both sectors are consistently more likely to choose advanced biology or chemistry, but more so in Arabic-language schools.

In columns (3) of Table 6 we add controls at the school level: school characteristics and electives offered in the school. ${ }^{28}$ We construct school level controls from summary statistics based on the full population of twelfth-grade students, restricting the analysis to students enrolled in schools with at least 30 students from the full population 29 School characteristics include: enrollment, share of female students, four-year or six-year school, school-level averages of GEMS scores and parental education, and the SES category of the school's municipality. Ayalon (2002)

\footnotetext{
${ }^{27}$ Full outputs for these regressions can be found in Table A5

${ }^{28}$ Including school fixed effects instead of observed characteristics yields similar results, available on request.

${ }^{29}$ Removing dropouts from the sample reduces sample size to 60,967, and removing students attending schools with enrollment lower than 30 students further reduces the sample by 111 observations, to 60,856 . Average enrollment per cohort in these years was 149 in Hebrew-language schools and 126 in Arabic-language schools.
} 
Table 6: Choice of advanced science and mathematics electives by gender, conditional on socioeconomic status, prior achievement and school characteristics.

\begin{tabular}{|c|c|c|c|c|c|c|c|c|c|}
\hline & \multicolumn{3}{|c|}{ Physics or computer science } & \multicolumn{3}{|c|}{ Advanced mathematics } & \multicolumn{3}{|c|}{ Biology or chemistry } \\
\hline & (1) & (2) & (3) & (1) & (2) & (3) & (1) & (2) & (3) \\
\hline & \multicolumn{9}{|c|}{ Difference in Difference } \\
\hline \multirow[t]{2}{*}{ Female, $\beta_{F}$} & $-0.10^{* * *}$ & $-0.12 * * *$ & $-0.13 * * *$ & $-0.02 * * *$ & $-0.04 * * *$ & $-0.04 * * *$ & $0.07 * * *$ & $0.04 * * *$ & $0.04 * * *$ \\
\hline & $(0.01)$ & $(0.00)$ & $(0.00)$ & $(0.00)$ & $(0.00)$ & $(0.00)$ & $(0.01)$ & $(0.01)$ & $(0.01)$ \\
\hline Arab, $\beta_{A}$ & $\begin{array}{l}-0.00 \\
(0.01)\end{array}$ & $\begin{array}{l}0.03 * * * \\
(0.01)\end{array}$ & $\begin{array}{l}0.02 \\
(0.01)\end{array}$ & $\begin{array}{l}0.03^{* *} \\
(0.01)\end{array}$ & $\begin{array}{l}0.07 * * * \\
(0.01)\end{array}$ & $\begin{array}{l}0.08 \\
(0.02)\end{array}$ & $\begin{array}{l}0.19^{* * *} \\
(0.02)\end{array}$ & $\begin{array}{l}0.24 * 2 \times-10 \\
(0.02)\end{array}$ & $\begin{array}{l}0.17 * * * 4 \\
(0.03)\end{array}$ \\
\hline \multirow[t]{3}{*}{ FemaleXArab, $\delta$} & $0.12 * * *$ & $0.10^{* * *}$ & $0.10^{* * *}$ & $0.05^{* * *}$ & $0.04 * * *$ & $0.04 * * *$ & $0.12 * * *$ & $0.09 * * *$ & $0.07 * * *$ \\
\hline & $(0.01)$ & $(0.01)$ & $(0.01)$ & $(0.01)$ & $(0.01)$ & $(0.01)$ & $(0.01)$ & $(0.01)$ & $(0.01)$ \\
\hline & \multicolumn{9}{|c|}{ Arab coefficients, estimated by gender $\left(\beta_{A}^{g}\right)$} \\
\hline \multirow{2}{*}{$\begin{array}{l}\text { Among females: } \\
\beta_{A}^{F}\end{array}$} & $0.09 * * *$ & & & & & & $0.34 * * *$ & & \\
\hline & $(0.01)$ & $(0.01)$ & $(0.02)$ & $(0.01)$ & $(0.01)$ & $(0.02)$ & (0.02) & $(0.02)$ & $(0.03)$ \\
\hline \multirow{3}{*}{$\begin{array}{l}\text { Among males: } \\
\beta_{A}^{M}\end{array}$} & & & & & & & & & \\
\hline & $0.02 *$ & $0.06 * * *$ & $0.07 * * *$ & $0.03 * *$ & $0.07 * * *$ & $0.11 * * *$ & $0.17 * * *$ & $0.21 * * *$ & $0.16^{* * * *}$ \\
\hline & $(0.01)$ & $(0.01)$ & $(0.02)$ & $(0.01)$ & $(0.01)$ & $(0.02)$ & $(0.02)$ & $(0.02)$ & $(0.02)$ \\
\hline$\beta_{A}^{F}-\beta_{A}^{M}$ & 0.07 & 0.04 & 0.02 & 0.05 & 0.03 & -0.01 & 0.17 & 0.15 & 0.09 \\
\hline Family SES & $\checkmark$ & $\checkmark$ & $\checkmark$ & $\checkmark$ & $\checkmark$ & $\checkmark$ & $\checkmark$ & $\checkmark$ & $\checkmark$ \\
\hline GEMS & & $\checkmark$ & $\checkmark$ & & $\checkmark$ & $\checkmark$ & & $\checkmark$ & $\checkmark$ \\
\hline School ch. & & & $\checkmark$ & & & $\checkmark$ & & & $\checkmark$ \\
\hline Share female & 0.497 & 0.497 & 0.519 & 0.497 & 0.497 & 0.519 & 0.497 & 0.497 & 0.519 \\
\hline$N$ & 68,050 & 68,050 & 60,856 & 68,050 & 68,050 & 60,856 & 68,050 & 68,050 & 60,856 \\
\hline
\end{tabular}

Notes: Dependent variables vary by vertical panel: choosing a matriculation elective in physics or computer science, advanced mathematics, and biology or chemistry. In the bottom panel equations are estimated separately by gender. Coefficients are obtained from a LPM with school-level clustered standard errors and a dummy for cohort. In columns (1), estimates are conditioned on family income quintiles, parents' maximal years of schooling and immigrant status. In columns (2), estimates are also conditioned on a second degree orthogonalized polynomial of the four GEMS scores (mathematics, science, reading and English) as well as an interaction between the reading and mathematics percentiles. All GEMS scores are normalized to have a mean of 0 and standard deviation of 1 . In columns (3) estimates are also conditioned on: school size, share of female students, four or six year school, school-level averages of GEMS scores, municipality SES, and indicators for the availability of matriculation elective categories. $\beta_{A}^{F}-\beta_{A}^{M}$ estimates ethnic differences in the gender gap when coefficients on the controls may vary by gender. Standard errors in parentheses. * $p<0.05 * * p<0.01 \quad * * * \quad p<0.001$ 
points to a difference between Arabic- and Hebrew-language schools in electives offered-fewer non-STEM matriculation electives in Arabic-language schools. To account for this we create a vector of dummy variables indicating whether at least $5 \%$ of students in the school took an advanced elective in the following categories: English, mathematics, physics or computer science, biology or chemistry, humanities, and other electives ${ }^{30}$

The results in columns (3) reveal that conditioning choice on school characteristics does not alter the estimated ethnic difference in gender gaps for physics or computer science and advanced mathematics. We do find that including these covariates significantly reduces the Arab coefficient, $\beta_{A}$, and slightly reduces the ethnic difference in the gender gap $\delta$, with regard to choosing biology or chemistry, indicating that differences in school characteristics and course offerings do explain to some extent differences between students in the two language sectors in choosing these science electives 31

In the bottom panel of Table 6, we estimate equation (2) for male and female students separately. The difference in coefficients $\beta_{A}^{F}-\beta_{A}^{M}$ estimates the difference in gender gaps between Arabic- and Hebrew-language schools, allowing gender differences in the coefficients. Allowing the effect of socio-economic background to vary by gender in columns (1) reduces the ethnic difference in the gender gap by $40 \%$ for choosing physics or computer science, compared to the raw differences in Table 2 ; only slightly reduces the difference in advanced mathematics; and increases it, from 0.13 to 0.17 , for biology or chemistry. Accounting for the different effect of prior achievement by gender in columns (2), reduces the ethnic difference in gender gaps further but it remains significantly positive in all subjects and large in biology or chemistry. Thus high school

\footnotetext{
${ }^{30}$ We do not observe all electives in our data. We define schools as offering "other electives" if at least $5 \%$ of the students in a schools are eligible for a matriculation certificate-meaning that they have at least 21 units- but for whom we see in our observed electives less than 21 units. In the full population, $28.2 \%$ of students fit this criteria. The choice of the $5 \%$ minimum is to ensure we capture a subject offered in the schools, rather than individual students taking matriculation elective in an extracurricular format, which is common for subjects like music and dance that fall into the "other electives" category, but rare for the mainstream electives.

${ }^{31}$ We do not observe teachers' gender or teacher practices, which are likely to be important (Dee, 2007). With respect to the gender composition of the teaching staff, we note that in both language sectors the teaching staff is predominantly female, but more so in Hebrew-language high schools, and the share of women among physics teachers is higher in Hebrew-language schools, where gender gaps favoring boys are higher. Potential differences between language sectors in the gender bias of teaching practices are most likely a function of culture, as Arab teachers teach almost only in Arab schools, and vice versa.
} 
increases the ethnic differences in gender gaps with respect to the choice of all three categories of STEM electives. In columns (3) allowing slopes on school characteristics to differ by gender further reduces the ethnic differences in gender gaps in physics or computer science and advanced mathematics. We cannot say whether this reflects sorting across schools or the effect of school characteristics on their students.

\subsection{Differences in the estimated gender gap for selected subsamples}

Most analyses of gender gaps in the choice of STEM study tracks are based on samples of high school or college bound students (Turner and Bowen, 1999, Riegle-Crumb et al., 2012; Arcidiacono, 2004; Arcidiacono and Koedel, 2013; Buser et al., 2014; Reuben et al., 2017). The prior selection implicit in these samples, especially samples of college students, suggests that their results may be biased with respect to population wide gender patterns ${ }^{32}$ Our main specification in Table 6 does not suffer from this bias as it estimates the ethnic difference in gender gaps using the full population of eighth-grade students, before students begin dropping out of school, with male dropout rates exceeding female dropout rates, and Arab male dropout rates exceeding all others ${ }^{33}$ This is our preferred specification. Table 7 presents estimates of our coefficients of interest, $\beta_{F}$, $\beta_{A}$, and $\delta$, for two alternative sample specifications, common in the literature, to facilitate comparisons to other studies: students enrolled in twelfth grade; and students eligible for a matriculation certificate (bound for tertiary education).

Limiting the sample to students enrolled in twelfth grade yields a slight increase in the relative propensity of Arab students to choose STEM matriculation subjects and a slight decrease in the propensity of female students to choose physics or computer science. The estimates of ethnic differences in gender gaps remain virtually unchanged, with a slight decrease for biology or chemistry. Leaving dropouts out of the sample has the expected effect of improving the relative position

\footnotetext{
32 Fryer and Levitt (2010) discuss this type of selection bias with respect to the estimation of gender gaps in SAT scores, where the share of women tested is larger, so that the female sample draws more heavily from the middle of the ability distribution.

${ }^{33}$ In Israel, up to eighth grade, dropout rates are negligible, less than $1 \%$.
} 
Table 7: Difference-in-difference estimates for different subsamples

\begin{tabular}{lccc}
\hline & $\begin{array}{c}\text { Physics or } \\
\text { computer science }\end{array}$ & $\begin{array}{c}\text { Advanced } \\
\text { mathematics }\end{array}$ & $\begin{array}{c}\text { Biology or } \\
\text { chemistry }\end{array}$ \\
\cline { 2 - 4 } Female, $\beta_{F}$ & $-0.12^{* * *}$ & $-0.04 * * *$ & $0.04 * * *$ \\
Arab, $\beta_{A}$ & $0.03 * * *$ & $0.07 * * *$ & $0.24 * * *$ \\
FemaleXArab, $\delta$ & $0.10^{* * *}$ & $0.04 * * *$ & $0.09 * * *$ \\
& & & \\
Female, $\beta_{F}$ & Students enrolled in twelfth grade $(\mathrm{N}=60,967)$ \\
Arab, $\beta_{A}$ & $-0.13^{* * *}$ & $-0.04 * * *$ & $0.04 * * *$ \\
FemaleXArab, $\delta$ & $0.04 * * *$ & $0.08^{* * *}$ & $0.28 * * *$ \\
& $0.10^{* * *}$ & $0.04 * * *$ & $0.07 * * *$ \\
Female, $\beta_{F}$ & & & \\
Arab, $\beta_{A}$ & Students eligible for matriculation certificate $(\mathrm{N}=37,843)$ \\
\cline { 2 - 4 } FemaleXArab, $\delta$ & $-0.20^{* * *}$ & $-0.07 * * *$ & $0.06 * * *$ \\
\hline
\end{tabular}

Notes: Dependent variables vary by column: choosing matriculation electives in physics or computer science; advanced mathematics; and biology or chemistry. Coefficients are obtained from a LPM with school-level clustered standard errors and a dummy for cohort. Estimates are conditioned on family income quintiles, parents' maximal years of schooling, immigrant status, a second degree orthogonalized polynomial of the four normalized GEMS scores (mathematics, science, reading and English) and an interaction between reading and mathematics percentiles. $* p<0.05 \quad * * p<0.01 \quad * * * p<0.001$ 
of the group that suffers most from dropouts—-male students in Arabic language schools—but it is a small effect. Significant differences arise when limiting the sample to students eligible for a matriculation certificate (college bound students). Here, the relative position of Arab students is dramatically improved, nearly doubled, in all choice categories, while estimated gender differences also increase-in favor of male students in physics or computer science and advanced mathematics, and in favor of female students in biology or chemistry. Conditional on matriculation, and our control variables, the two ethnic groups exhibit similar gender patterns in advanced mathematics and biology or chemistry ( $\delta$ is not significantly different from 0 ), however, the ethnic difference in the underrepresentation of women in physics or computer science remains practically unchanged.

\section{Ethnic-gender differences in the marginal effect of prior achievement}

As the choice models under uncertainty of Altonji (1993) and Arcidiacono (2004) highlight, test scores serve as a signal of ability for the student. Lower GEMS achievement levels are adverse signals, and previous research on gender differences in risk aversion and competitiveness suggests that boys are less deterred by adverse signals in choosing STEM subjects. In Friedman-Sokuler and Justman (2016) we found that the probability of choosing any STEM elective increases in eighth-grade mathematics and science scores, but the slope was steeper for boys with regard to choosing advanced mathematics and physics or computer science, and steeper for girls with respect to choosing biology or chemistry. In section 5 we show that allowing the effect of prior achievement on the propensity to choose electives to vary by gender has a substantial effect on the ethnic difference in gender gaps. In this section we compare gender differences in the effect of prior scores across ethnic groups.

This is captured graphically in Figure 2, which shows the propensity of choosing each of the three advanced STEM matriculation categories, by the percentile of achievement in GEMS mathematics, for each of the four gender-language combinations. All twelve propensities increase in 
eighth-grade mathematics achievement, but at different rates, depending on gender, ethnicity and subject category. These differences in the relationship between prior achievement and choice can explain some of the ethnic differences in gender gaps. In panel (a) of Figure 2 , students in Hebrewlanguage schools exhibit a large gender gap in the propensity to choose physics or computer science which increases as a function of prior mathematics achievement, where we observe no such gender gap among students in Arabic-language schools. Gender and ethnic differences are smallest with respect to the propensity to choose advanced mathematics, in panel (b). However, where the male propensity is slightly greater than the female propensity in Hebrew-language schools, the opposite is true in Arabic-language schools. With regard to the choice of biology and chemistry as a function of eighth-grade mathematics, in panel (c), we find a gender gap favoring female students in both language sectors, but larger in Arabic-language schools. All of this highlights the role of cultural conditioning in shaping the different response, by gender, to prior achievement.

Table 8 quantifies this analysis for science electives, estimating the probability of choosing advanced science electives for each gender-language combination separately, conditional on socioeconomic status and polynomials of prior achievement ${ }^{34}$ The regression results accord with the graphical analysis in Figure 2. For physics or computer science, we find no statistically significant gender differences in the response to prior achievement in Arabic-language schools and substantial differences by gender in Hebrew-language schools, where positive coefficients of prior scores are much larger for males than females. With respect to the choice of biology or chemistry, in Hebrewlanguage schools all the GEMS coefficients are positive and larger for female students, where in Arabic-language schools the marginal effect of mathematics achievement is twice as large for male students as for female students, while other coefficients are larger for female students. Moreover, for Arab female students, achievement in reading and English are stronger predictors for the choice of biology and chemistry than mathematics achievement. Arab girls who are good at mathematics go into physics or computer science or advanced mathematics, while those who are good students in general, but less so in mathematics, choose biology and chemistry.

\footnotetext{
${ }^{34}$ We omit advanced mathematics for brevity. Science electives exhibit larger gender and ethnic differences. Results for advanced mathematics are available upon request.
} 
Figure 2: Share choosing science electives by gender and language sector, by eighth-grade mathematics and reading scores

(a) Share choosing physics or computer science

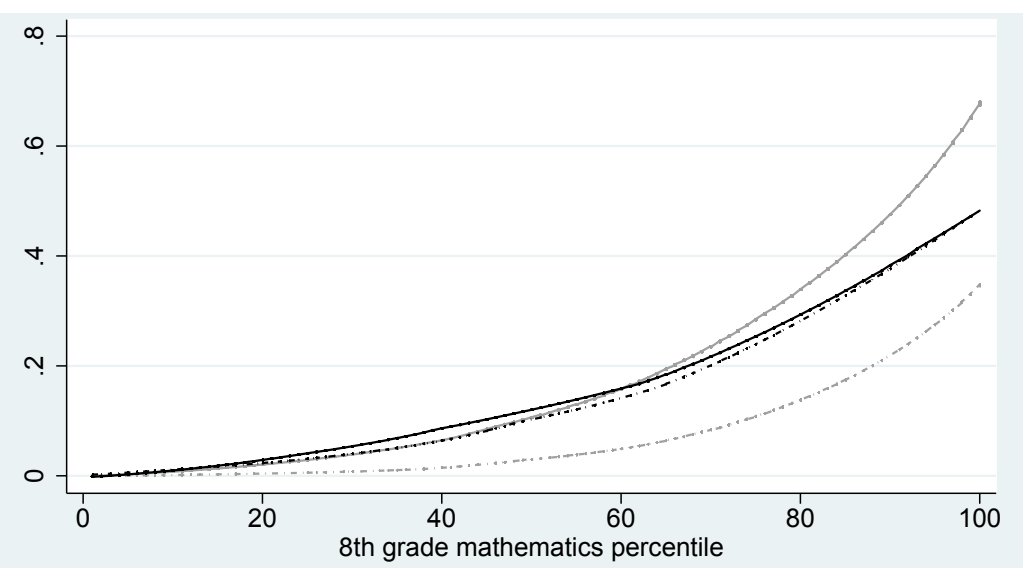

(b) Share choosing advanced mathematics

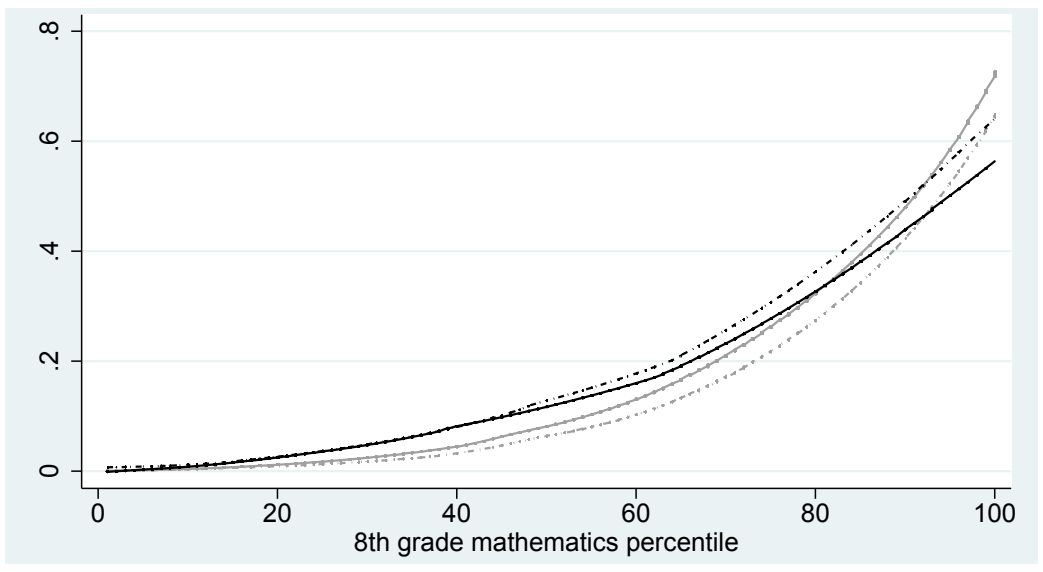

(c) Share choosing biology or chemistry

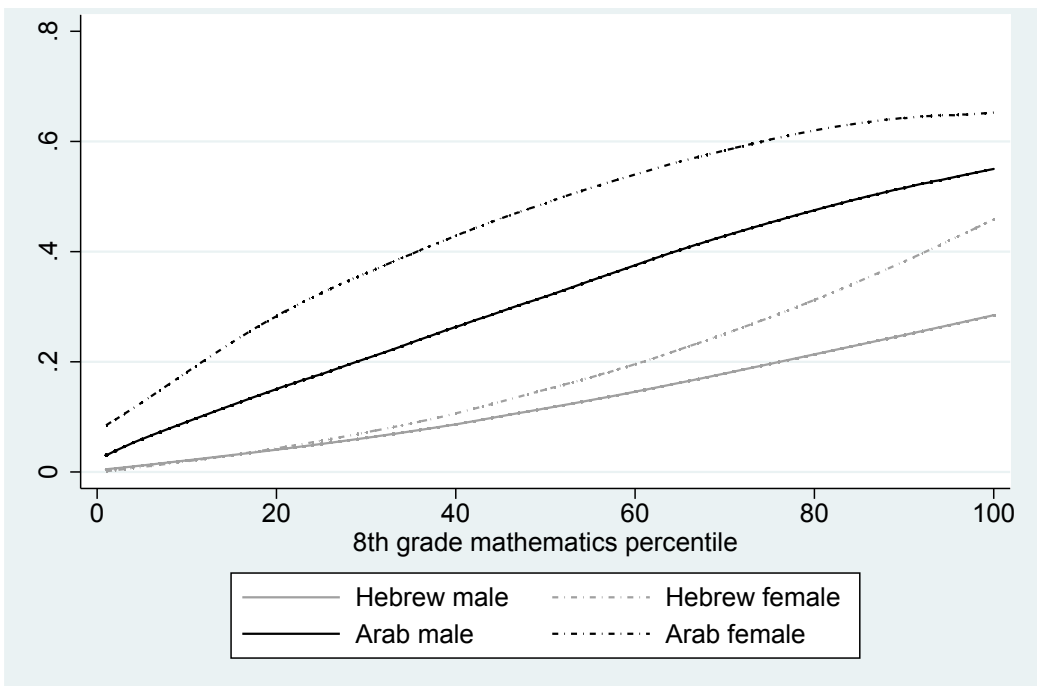

Notes: Graphs represent share of students tested in each matriculation elective, by eighth-grade mathematics achievement percentiles. Percentiles are defined over the whole population. Lines are smoothed using Stata's Lowess procedure for kernel-weighted local polynomial smoothing $\quad 28$ 
Table 8: Choice of advanced science electives estimated separately by gender-ethnic groups, conditional on prior achievement and socio-economic status

\begin{tabular}{|c|c|c|c|c|c|c|c|c|}
\hline & \multicolumn{4}{|c|}{ Physics or computer science } & \multicolumn{4}{|c|}{ Biology or chemistry } \\
\hline & \multicolumn{2}{|c|}{ Hebrew } & \multicolumn{2}{|c|}{ Arabic } & \multicolumn{2}{|c|}{ Hebrew } & \multicolumn{2}{|c|}{ Arabic } \\
\hline & Male & Female & Male & Female & Male & Female & Male & Female \\
\hline \multicolumn{9}{|l|}{ GEMS } \\
\hline Mathematics & $\begin{array}{l}0.09 * * * \\
(0.00)\end{array}$ & $\begin{array}{l}0.04 * * * \\
(0.00)\end{array}$ & $\begin{array}{l}0.07 * * * \\
(0.01)\end{array}$ & $\begin{array}{l}0.06^{* * * *} \\
(0.01)\end{array}$ & $\begin{array}{l}0.03 * * * \\
(0.00)\end{array}$ & $\begin{array}{l}0.06 * * * \\
(0.00)\end{array}$ & $\begin{array}{l}0.07 * * * \\
(0.01)\end{array}$ & $\begin{array}{l}0.03^{*} \\
(0.02)\end{array}$ \\
\hline Science & $\begin{array}{l}0.04 * * * \\
(0.00)\end{array}$ & $\begin{array}{l}0.02 * * * \\
(0.00)\end{array}$ & $\begin{array}{l}0.02 * * * \\
(0.01)\end{array}$ & $\begin{array}{l}0.02 * * * \\
(0.01)\end{array}$ & $\begin{array}{l}0.03^{* * * *} \\
(0.00)\end{array}$ & $\begin{array}{l}0.05 * * * \\
(0.00)\end{array}$ & $\begin{array}{l}0.04 * * \\
(0.01)\end{array}$ & $\begin{array}{l}0.05 * * * \\
(0.01)\end{array}$ \\
\hline Reading & $\begin{array}{l}0.03^{* * * *} \\
(0.00)\end{array}$ & $\begin{array}{l}0.01 * * \\
(0.00)\end{array}$ & $\begin{array}{l}0.05^{* * * *} \\
(0.01)\end{array}$ & $\begin{array}{l}0.05^{* * * *} \\
(0.01)\end{array}$ & $\begin{array}{l}0.02 * * * \\
(0.00)\end{array}$ & $\begin{array}{l}0.03^{* * * *} \\
(0.00)\end{array}$ & $\begin{array}{l}0.08^{* * * *} \\
(0.01)\end{array}$ & $\begin{array}{l}0.09 * * * \\
(0.01)\end{array}$ \\
\hline English & $\begin{array}{l}0.02 * * * \\
(0.00)\end{array}$ & $\begin{array}{l}0.00 * * \\
(0.00)\end{array}$ & $\begin{array}{l}0.03^{* * *} * \\
(0.01)\end{array}$ & $\begin{array}{l}0.02 * * * \\
(0.01)\end{array}$ & $\begin{array}{l}0.02 * * * \\
(0.00)\end{array}$ & $\begin{array}{l}0.02 * * * \\
(0.00)\end{array}$ & $\begin{array}{l}0.01 \\
(0.01)\end{array}$ & $\begin{array}{l}0.05^{* * * *} \\
(0.01)\end{array}$ \\
\hline Mathematics X Reading & $\begin{array}{l}0.03 * * * \\
(0.00)\end{array}$ & $\begin{array}{l}0.01 * * * \\
(0.00)\end{array}$ & $\begin{array}{l}0.03^{* * * *} \\
(0.01)\end{array}$ & $\begin{array}{l}0.03^{* * * *} \\
(0.01)\end{array}$ & $\begin{array}{l}0.01 * * \\
(0.00)\end{array}$ & $\begin{array}{l}0.02^{* * * *} \\
(0.00)\end{array}$ & $\begin{array}{l}0.02 * * \\
(0.01)\end{array}$ & $\begin{array}{l}-0.01 \\
(0.01)\end{array}$ \\
\hline \multicolumn{9}{|l|}{ GEMS $^{2}$} \\
\hline Mathematics & $\begin{array}{l}0.06 * * * \\
(0.00)\end{array}$ & $\begin{array}{l}0.04 * * * \\
(0.00)\end{array}$ & $\begin{array}{l}0.02 * * \\
(0.01)\end{array}$ & $\begin{array}{l}0.03 * * * \\
(0.01)\end{array}$ & $\begin{array}{l}0.00 \\
(0.00)\end{array}$ & $\begin{array}{l}0.01 * * \\
(0.00)\end{array}$ & $\begin{array}{l}-0.01 \\
(0.01)\end{array}$ & $\begin{array}{l}-0.02 \\
(0.01)\end{array}$ \\
\hline Science & $\begin{array}{l}0.02 * * * \\
(0.00)\end{array}$ & $\begin{array}{l}0.01 * * * \\
(0.00)\end{array}$ & $\begin{array}{l}0.02 * * * \\
(0.00)\end{array}$ & $\begin{array}{l}0.01^{*} \\
(0.01)\end{array}$ & $\begin{array}{l}0.02 * * * \\
(0.00)\end{array}$ & $\begin{array}{l}0.02 * * * \\
(0.00)\end{array}$ & $\begin{array}{l}0.01 \\
(0.01)\end{array}$ & $\begin{array}{l}0.00 \\
(0.01)\end{array}$ \\
\hline Reading & $\begin{array}{l}0.01 * * \\
(0.00)\end{array}$ & $\begin{array}{l}0.00 \\
(0.00)\end{array}$ & $\begin{array}{l}0.01 \\
(0.01)\end{array}$ & $\begin{array}{l}0.02 * * * \\
(0.00)\end{array}$ & $\begin{array}{l}0.00 \\
(0.00)\end{array}$ & $\begin{array}{l}0.01 \\
(0.00)\end{array}$ & $\begin{array}{l}-0.02 * \\
(0.01)\end{array}$ & $\begin{array}{l}0.00 \\
(0.01)\end{array}$ \\
\hline English & $\begin{array}{l}0.01 \text { *** } \\
(0.00)\end{array}$ & $\begin{array}{l}0.00 \\
(0.00)\end{array}$ & $\begin{array}{l}0.01 * \\
(0.00)\end{array}$ & $\begin{array}{l}0.01^{*} \\
(0.00)\end{array}$ & $\begin{array}{l}0.01 \text { *** } \\
(0.00)\end{array}$ & $\begin{array}{l}0.01 \text { *** } \\
(0.00)\end{array}$ & $\begin{array}{l}0.01 * \\
(0.01)\end{array}$ & $\begin{array}{l}0.02 * \\
(0.01)\end{array}$ \\
\hline Constant & $\begin{array}{l}0.11^{* * * *} \\
(0.01)\end{array}$ & $\begin{array}{l}0.03^{* * *} \\
(0.01)\end{array}$ & $\begin{array}{l}0.14 * * * \\
(0.01)\end{array}$ & $\begin{array}{l}0.10^{\text {*** }} \\
(0.01)\end{array}$ & $\begin{array}{l}0.09 * * * \\
(0.01)\end{array}$ & $\begin{array}{l}0.10^{* * * *} \\
(0.01)\end{array}$ & $\begin{array}{l}0.29 * * * \\
(0.02)\end{array}$ & $\begin{array}{l}0.42 * * * \\
(0.03)\end{array}$ \\
\hline Observations & 26,061 & 25,529 & 8,190 & 8,270 & 26,061 & 25,529 & 8,190 & 8,270 \\
\hline R-squared & 0.299 & 0.146 & 0.226 & 0.214 & 0.092 & 0.144 & 0.184 & 0.196 \\
\hline
\end{tabular}

Notes: Dependent variables vary by vertical panel: choosing physics or computer science and biology or chemistry. Samples vary by column. Coefficients are obtained from a LPM conditional on parents' maximal years of education and family income quintiles, with school-level clustered standard errors and a dummy for cohort and immigrant. All GEMS scores are normalized to have a mean of 0 and standard deviation of 1 . Standard errors in parentheses. * $p<0.05 \quad * * p<0.01 \quad * * * p<0.001$ 


\section{Discussion}

The previous sections established that differences in gender gaps in achievement between Hebrewand Arabic-language schools are only partially explained by population differences in socioeconomic characteristics, and that differences in gendered choice patterns in matriculation are only partially accounted for by socio-economic characteristics or by gaps favoring Arab girls in eighthgrade achievement. The finding that girls in the ethnic group with less gender equality perform better and take more STEM majors accords with and extends Fryer and Levitt's 2010 findings on the mathematics gap favoring girls in Arab (Muslim) countries. It indicates that this pattern persists in other contexts and is not limited to achievement on international exams, but also extends to the choice of STEM matriculation electives.

Both in Israel and in the Arab world, these patterns are not reflected in the labor market. In Israel, the Arab female labor force participation rate is $28 \%$, much lower than for Arab men and Jewish women, 64\% and 66\% respectively (Central Bureau of Statistics, 2015). This low participation rate is similar to those of women in other Arab countries (Yashiv and Kasir, 2015). Arab women in Israel are often employed in occupations that do not require a matriculation certificate or tertiary qualifications in STEM subjects, such as personal care and sales, which account for $43 \%$ of the Arab women in the labor force (Central Bureau of Statistics, 2013, Table 2.17). Among those in professional occupations, the under-representation of women relative to men in science, engineering and IT occupations is similar in both ethnic groups $\sqrt{55}$ Even within the teaching profession, the second largest category of employment among Arab women, female teachers constitute $73 \%$ of all Arab teaching professionals, but only $26 \%$ of physics teachers in Arab schools, compared to $40 \%$ in Hebrew schools (Knesset Research and Information Center, 2012) ${ }^{36}$ However, Arab society in Israel is undergoing a cultural shift towards modernity, as are many countries in the Middle East and North Africa, a shift reflected in, among other things, the reversal of gender gaps in education

\footnotetext{
${ }^{35}$ Only $1 \%$ of Arab women are science and engineering or IT professionals, compared to $3 \%$ of Arab men, $5 \%$ of Jewish women and 10\% of Jewish men (Central Bureau of Statistics. 2013. Table 2.17).

${ }^{36}$ Almost all teachers in Arab schools are Arabs and all teachers in Hebrew schools are Jews or other. Similar ethnic differences in gender gaps are found in chemistry and biology where about half of the teachers in Arabic schools are female compared to more than $80 \%$ in Hebrew schools.
} 
(Bossavie and Kanninen, 2018). Current gendered patterns in the labor market cannot fully reflect such changes as are taking place within younger cohorts.

Akerlof and Kranton (2000), in explaining occupational gender segregation, and the earlier sorting into study fields, emphasize the notion that specific occupations are associated with the social categories "man" and "woman". Nosek et al. (2009), using implicit association tests, identify systematic variation across 34 countries in implicit attitudes associating men with science more than women, and show that this gender bias strongly correlates with nation-wide male-tofemale achievement gaps in eighth-grade TIMSS science and mathematics scores, but not with self-reported stereotypes. They find that Hebrew speaking participants from Israel exhibit aboveaverage implicit gender bias: ${ }^{37}$ while countries such as Jordan and Iran exhibit below-average levels of implicit stereotypes. These findings indicate the presence of cultural differences in the association between science and gender which are independent of cultural differences regarding overall gender equality. This suggests that as the share of Arab women in the labor market increases the share of Arab women in STEM occupations may also increase 38

At the same time, there are also indications that marriage market incentives act as cultural mechanisms that induce investment in education and human capital, which may not necessarily translate into increased female participation in the labor force in STEM occupations. Prior evidence indicates that investment in the education of young women in traditional societies is related to their prospects in the marriage market (Hu and Schlosser, 2015; Ashraf et al., 2016). In this vein, Read and Cohen (2007) analyze United States Census data and find that the link between education and employment is inconsistent across ethnic groups - the combination of high education and low employment is evident among Arab, Iranian, Korean, and Asian Indian women. Ethnographic studies of Arab women in Israel and the United States provide further support, finding that because women in Arab society are responsible for the socialization and education of their children to a greater extent than women in Western societies, their own education is valued more as a resource

\footnotetext{
${ }^{37}$ The sample from Israel did not include the Arab minority

${ }^{38}$ The limited supply of jobs in the largest occupation for educated Arab women—teaching—may also contribute to this trend (Zur 2017).
} 
for the home than as an asset in the labor market (Sa'ar, 2006; Read and Oselin, 2008).

Finally, Arabic- and Hebrew-speaking young women face different empirical realities—shaped by culture. While Hebrew speaking women may have greater opportunities to take advantage of a STEM education in the labor market, Arab women may pay a greater price for not pursuing a STEM education. Sabbah-Karkaby and Stier 2017) examined marital behavior in Arab society in Israel with relation to educational attainment. They find that the increase in female education changed the link between education and age at marriage. While young age is considered an asset in the marriage market, higher education is becoming more important over time, thus allowing some postponement of marriage. However, the pursuit of post-secondary education still requires the consent of the men in the family, which is conditioned on proof of ability and high levels of achievement in secondary education (Seginer and Vermulst, 2002). This provides added incentive for Arab girls to take on challenging matriculation electives, such as physics and advanced mathematics, to prove their potential. Currently most do not persist in these fields into tertiary education and the labor market, but the potential is there.

\section{Concluding remarks}

In this paper we point to the role of culturally conditioned gender norms in shaping gender gaps in educational achievement and choice. We do so by comparing two distinct ethno-linguistic groups, Hebrew and Arabic speakers in Israel, attending separate coeducational schools within the same highly centralized education system. In eighth-grade achievement, students in Hebrew-language schools outperform those in Arabic-language schools, and girls outperform boys. In line with the findings of Fryer and Levitt (2010), we show that, in middle school, the advantage of girls over boys in mathematical achievement in the predominantly Muslim, Arabic-language sector, characterized by patriarchal-traditional cultural norms, is greater than in the predominantly Jewish, Hebrewlanguage sector characterized by western-egalitarian gender norms. We find that the lower level of SES of the Arab population accounts for about half of the gap in favour of Jewish students, but 
explains only a small fraction of the difference in gender gaps.

We extend these finding to twelfth-grade attainment and matriculation choices. We find that retention and matriculation rates are higher for students in Hebrew-language schools than for students in Arabic-language schools and higher for female students than for male students; and that the gender gap favoring females is again larger in Arabic-language schools. We find that differences in SES and prior achievement account for the entire gap between language sectors, and reduce gender gaps by 30-50\%, while the differences in gender gaps, favoring girls in Arabiclanguage schools, remains significantly positive and substantial after controlling for SES and prior scores.

A more complex picture emerges with respect to the choice of STEM matriculation electives. Students in Arabic-language schools choose biology and chemistry at higher rates than students in Hebrew-language schools while the opposite is true for advanced mathematics, computer science and to a lesser extent physics. Gender patterns with respect to the latter three subject differ between language sectors-Arab girls are slightly overrepresented in advanced mathematics and physics, while girls in Hebrew-language schools are significantly under-represented. Moreover, while in Hebrew-language schools the gender gaps favoring men in physics, computer science and advanced mathematics electives increases in early mathematical achievement, in Arabic-language schools gender gaps favoring men in these subjects are non-existent on average and reversed among top achieving students.

This inverse relationship between societal levels of gender equality and gender equality in STEM related educational choices and outcomes, suggests that culture, manifested in gender norms, is not a single factor but rather a multiplicity of forces shaping educational outcomes. Our reading of the literature suggests three such channels operating in the Israeli context. First, the stereotype that associates science with masculinity, which contributes to the persistence of gender gaps in Western societies, is much weaker in Arab society. Second, cultural differences in gender norms yields larger returns to female education in the Arab marriage market. Third, the patriarchal structure of Arab society provides added incentive for Arab girls to excel in mathematically 
intensive fields, to signal their greater academic potential to their family if they are to gain access to higher education. These channels, while context specific, point to the need to widen the perspective through which we understand the ways in which culture and norms shape gender gaps in education and in the labor market.

From a policy perspective, these findings suggest different approaches to promoting female participation in STEM occupations for each ethnic group. The relatively large share of Arab women completing high school with qualifications that allow them to continue to mathematically intensive tertiary degrees in IT and engineering, suggests that policy measures in this sector should focus on the transition from secondary to tertiary education, and on fostering opportunities in the labor market. In the Hebrew-language sector, where women are under-represented in science and mathematics already in secondary school, our analysis points to the need to identify and address societal and normative structures that shape gender streaming at earlier stages in the educational pipeline.

\section{References}

Abu-Baker, K. (1998) Modern welfare and tradition: Palestinian women in israel coping with changes in their life settings, in Hebrew, in The Arab Society in Israel Book 2: Population, Society, Economy (Ed.) A. Manna, Van Leer Institute and Kibbutz Meuchad Publishers, Jerusalem.

Abu-Baker, K. and Azaiza, F. (2010) Strategies for closing the educational gaps among Palestinian couples in Israel, Hawwa, 8, 154-180.

Akerlof, G. A. and Kranton, R. E. (2000) Economics and identity, The Quarterly Journal of Economics, 115, 715-753.

Altonji, J. G. (1993) The demand for and return to education when education outcomes are uncertain, Journal of Labor Economics, 11, pp. 48-83.

Antecol, H. (2000) An examination of cross-country differences in the gender gap in labor force participation rates, Labour Economics, 7, 409 - 426. 
Arcidiacono, P. (2004) Ability sorting and the returns to college major, Journal of Econometrics, $121,343-375$.

Arcidiacono, P. and Koedel, C. (2013) Race and college success: Evidence from Missouri, Working Paper 19188, National Bureau of Economic Research.

Ashraf, N., Bau, N., Nunn, N. and Voena, A. (2016) Bride price and female education, Working Paper 22417, National Bureau of Economic Research.

Ayalon, H. (2002) Mathematics and sciences course taking among Arab students in Israel: A case of unexpected gender equality, Educational Evaluation and Policy Analysis, 24, 63-80.

Bargain, O., González, L., Keane, C. and Özcan, B. (2012) Female labor supply and divorce: New evidence from Ireland, European Economic Review, 56, 1675 - 1691.

Benavot, A. and Resh, N. (2003) Educational governance, school autonomy, and curriculum implementation: A comparative study of Arab and Jewish schools in Israel, Journal of Curriculum Studies, 35, 171-196.

Birenbaum, M. and Nasser, F. (2006) Ethnic and gender differences in mathematics achievement and in dispositions towards the study of mathematics, Learning and Instruction, 16, 26 - 40.

Birenbaum, M., Nasser, F. and Tatsuoka, C. (2007) Effects of gender and ethnicity on fourth graders' knowledge states in mathematics, International Journal of Mathematical Education in Science and Technology, 38, 301-319.

Blass, N., Tsur, S. and Zussman, N. (2010) The allocation of teachers' working hours in primary education, 2001-09, Working Paper 2010.18, Research Department, Bank of Israel.

Blau, F. D. and Kahn, L. M. (2017) The gender wage gap: Extent, trends, and explanations, Journal of Economic Literature, 55, 789-865.

Bossavie, L. and Kanninen, O. (2018) What explains the gender gap reversal in education? The role of the tail hypothesis, Working Paper 8303, World Bank. 
Buser, T., Niederle, M. and Oosterbeek, H. (2014) Gender, competitiveness, and career choices, The Quarterly Journal of Economics, 129, 1409-1447.

Ceci, S. J., Ginther, D. K., Kahn, S. and Williams, W. M. (2014) Women in academic science: A changing landscape, Psychological Science in the Public Interest, 15, 75-141.

Central Bureau of Statistics (2003) Statistical Abstract of Israel, http://www . cbs . gov . il/ reader/shnatonhnew_site.htm.

Central Bureau of Statistics (2013) Labor Force Survey of Israel, http : / / www • cbs • gov • il/ reader/y_labor/yearm_h_new.htm?CYear_co=2007\#6.

Central Bureau of Statistics (2015) Statistical Abstract of Israel, http://www . cbs . gov . il/ reader/shnatonhnew_site.htm.

Cinamon, R. G. (2009) Role salience, social support, and work-family conflict among Jewish and Arab female teachers in Israel, Journal of Career Development, 36, 139-158.

Dee, T. S. (2007) Teachers and the gender gaps in student achievement, The Journal of Human Resources, 42, 528-554.

DiPrete, T. A. and Jennings, J. L. (2012) Social and behavioral skills and the gender gap in early educational achievement, Social Science Research, 41, 1-15.

Dwairy, M. (1997) Personality, culture, and Arab society, Al Noor Press.

Dwairy, M. (2004) Parenting styles and mental health of Palestinian-Arab adolescents in Israel, Transcultural Psychiatry, 41, 233-252.

Dwyer, R. E., Hodson, R. and McCloud, L. (2013) Gender, debt, and dropping out of college, Gender \& Society, 27, 30-55.

Feniger, Y. (2010) The gender gap in advanced math and science course taking: Does same-sex education make a difference?, Sex Roles, 65, 670-679. 
Fernández, R. (2011) Does culture matter?, North-Holland, vol. 1 of Handbook of Social Economics, pp. $481-510$.

Fernández, R. and Fogli, A. (2006) Fertility: The role of culture and family experience, Journal of the European Economic Association, 4, 552-561.

Fernández, R. and Fogli, A. (2009) Culture: An empirical investigation of beliefs, work, and fertility, American Economic Journal: Macroeconomics, 1, 146-177.

Fogiel-Bijaoui, S. (2002) Familism, postmodernity and the state: The case of Israel, Journal of Israeli History, 21, 38-62.

Friedman-Sokuler, N. and Justman, M. (2016) Gender streaming and prior achievement in high school science and mathematics, Economics of Education Review, 53, 230 - 253.

Fryer, R. G. and Levitt, S. D. (2010) An empirical analysis of the gender gap in mathematics, American Economic Journal: Applied Economics, 2, pp. 210-240.

Gharrah, R. (2015) Arab Society in Israel (7): Population, Society, Economy, Van Leer Jerusalem

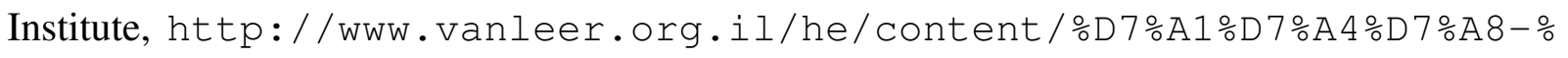
D 7으은

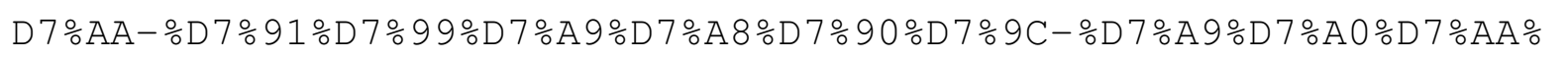
D 7으을

Goldin, C., Katz, L. F. and Kuziemko, I. (2006) The homecoming of American college women: The reversal of the college gender gap, The Journal of Economic Perspectives, 20, 133-156.

Guiso, L., Monte, F., Sapienza, P. and Zingales, L. (2008) Culture, gender, and math, Science, 320, 1164-1165.

Hu, L. and Schlosser, A. (2015) Prenatal sex selection and girls' well-being: Evidence from India, The Economic Journal, 125, 1227-1261. 
Justman, M. (2014) Differential budgeting in education: Agreement in principle, difficulties in implementation (Hebrew), prepared for Eli Hurvitz Conference on Economy and Society, The Van Leer Jerusalem Institute.

Justman, M. and Méndez, S. J. (2018) Gendered choices of STEM subjects for matriculation are not driven by prior differences in mathematical achievement, Economics of Education Review, forthcoming.

Kalekin-Fishman, D. (2004) Ideology, Policy, and Practice: Education for Immigrants and Minorities in Israel Today.

Knesset Research and Information Center (2012) Statistics on teaching staff in science and technology, https://www.knesset.gov.il/mmm/data/pdf/m03089.pdf.

Lavy, V. (1998) Disparities between Arabs and Jews in school resources and student achievement in Israel, Economic Development and Cultural Change, 47, pp. 175-192.

Nollenberger, N., Rodríguez-Planas, N. and Sevilla, A. (2016) The math gender gap: The role of culture, American Economic Review, 106, 257-61.

Nosek, B. A., Smyth, F. L., Sriram, N., Lindner, N. M., Devos, T., Ayala, A., Bar-Anan, Y., Bergh, R., Cai, H., Gonsalkorale, K., Kesebir, S., Maliszewski, N., Neto, F., Olli, E., Park, J., Schnabel, K., Shiomura, K., Tulbure, B. T., Wiers, R. W., Somogyi, M., Akrami, N., Ekehammar, B., Vianello, M., Banaji, M. R. and Greenwald, A. G. (2009) National differences in gender-science stereotypes predict national sex differences in science and math achievement, Proceedings of the National Academy of Sciences, 106, 10593-10597.

OECD (2016) Education policy outlook country profile: Israel, http://wWw.oecd.org/ israel/Education-Policy-Outlook-Country-Profile-Israel.pdf.

Oyserman, D. (1993) The lens of personhood: Viewing the self and others in a multicultural society, Journal of Personality and Social Psychology, 65, 993 - 1009. 
Rapoport, B. and Thibout, C. (2018) Why do boys and girls make different educational choices? The influence of expected earnings and test scores, 62, 205-229.

Rapp, J. (2015) Gender gaps in mathematics and language in Israel- What can be learned from the Israeli case?, Working paper, National Authority for Measurement and Evaluation in Education.

Read, J. G. and Cohen, P. N. (2007) One size fits all? Explaining U.S.-born and immigrant women's employment across 12 ethnic groups, Social Forces, 85, 1713-1734.

Read, J. G. and Oselin, S. (2008) Gender and the education-employment paradox in ethnic and religious contexts: The case of Arab Americans, American Sociological Review, 73, 296-313.

Reuben, E., Wiswall, M. and Zafar, B. (2017) Preferences and biases in educational choices and labour market expectations: Shrinking the black box of gender, The Economic Journal, 127, $2153-2186$.

Riegle-Crumb, C., King, B., Grodsky, E. and Muller, C. (2012) The more things change, the more they stay the same? Prior achievement fails to explain gender inequality in entry into fSTEM college majors over time, American Educational Research Journal, 49, 1048-1073.

Sa'ar, A. (2006) Feminine strength: Reflections on power and gender in Israeli-Palestinian culture, Anthropological Quarterly, 79, 397-430.

Sabbah-Karkaby, M. and Stier, H. (2017) Links between education and age at marriage among Palestinian women in Israel: Changes over time, Studies in Family Planning, 48, 23-38.

Seginer, R. and Vermulst, A. (2002) Family environment, educational aspirations, and academic achievement in two cultural settings, Journal of Cross-Cultural Psychology, 33, 540-558.

Shir, T. (2014) Gender segregation in Hebrew state religious primary schools, Working Paper 2014.06, Research Department, Bank of Israel. 
Sutter, M., Angerer, S., Glätzle-Rützler, D. and Lergetporer, P. (2018) Language group differences in time preferences: Evidence from primary school children in a bilingual city, European Economic Review, 106, 21 - 34.

Turner, S. E. and Bowen, W. G. (1999) Choice of major: The changing (unchanging) gender gap, Industrial and Labor Relations Review, 52, 289 - 313.

United Nations Economic Commission for Europe (2015) Indicators of Gender Equality, http: //http://www. unece.org/index.php?id=38461\&L=0,

Yashiv, E. and Kasir, N. (2011) Patterns of labor force participation among Israeli Arabs, Israel Economic Review, 9.

Yashiv, E. and Kasir, N. (2015) The labour market of Israeli Arabs: Key features and policy solutions, Policy Insight 78, Centre for Economic Policy Research.

Zur, Y. (2017) 11,000 Arab teachers in Israel unemployed while Jewish schools face teacher shortage, Haaretz, https://www.haaretz.com/israel-news/ $11 \mathrm{k}$-arab-teachers-unemployed-as-jewish-schools-face-teacher-shortage-1. 5628951 . 


\section{A1 Attrition}

Figure A1 graphically compares female to male ratios by percentile of twelfth-grade mathematics matriculation scores across samples. In both language sectors and in all samples the patterns of gender ratios are nearly identical: girls in Hebrew language schools are under-represented in the top decile of mathematical achievement, while Arabic girls are substantially over-represented. In Arabic-language schools, the high end of the score distribution is affected by the omission of Arabic Church schools from the GEMS and study sample, but this has little effect on the ethnic differences in gender ratios. Table A1 numerically compares ethnic differences in gender gaps in raw $12^{\text {th }}$ grade attainment and choice rates between the full population and the study sample separately for Arabic- and Hebrew-language schools. The population and study sample ratios are similar.

Table A1: Gender gaps in twelfth-grade attainment and subject choice, in the full population and the study sample, by language sector

\begin{tabular}{|c|c|c|c|c|c|c|}
\hline & \multicolumn{3}{|c|}{ Arabic-language schools } & \multicolumn{3}{|c|}{ Hebrew-language schools } \\
\hline & \multicolumn{2}{|c|}{$\mathrm{F} / \mathrm{M}$ ratio } & \multirow{3}{*}{$\begin{array}{c}(c) \\
(a) /(b)\end{array}$} & \multicolumn{2}{|c|}{$\mathrm{F} / \mathrm{M}$ ratio } & \multirow{3}{*}{$\begin{array}{c}\text { (f) } \\
\text { (d)/(e) }\end{array}$} \\
\hline & (a) & (b) & & (d) & (e) & \\
\hline & Population & Study & & Population & Study & \\
\hline Reached 12th grade & 1.27 & 1.21 & 1.05 & 1.09 & 1.06 & 1.03 \\
\hline Matriculated & 1.86 & 1.77 & 1.05 & 1.29 & 1.22 & 1.06 \\
\hline Physics or computer science & 1.10 & 1.16 & 0.95 & 0.41 & 0.41 & 1.00 \\
\hline Advanced mathematics & 1.40 & 1.43 & 0.98 & 0.91 & 0.88 & 1.03 \\
\hline Biology or chemistry & 1.91 & 1.83 & 1.04 & 1.55 & 1.50 & 1.03 \\
\hline
\end{tabular}


Figure A1: Female to male ratio by achievement percentile of weighted mathematics matriculation scores, by language sector and sample using Lowess smoothing

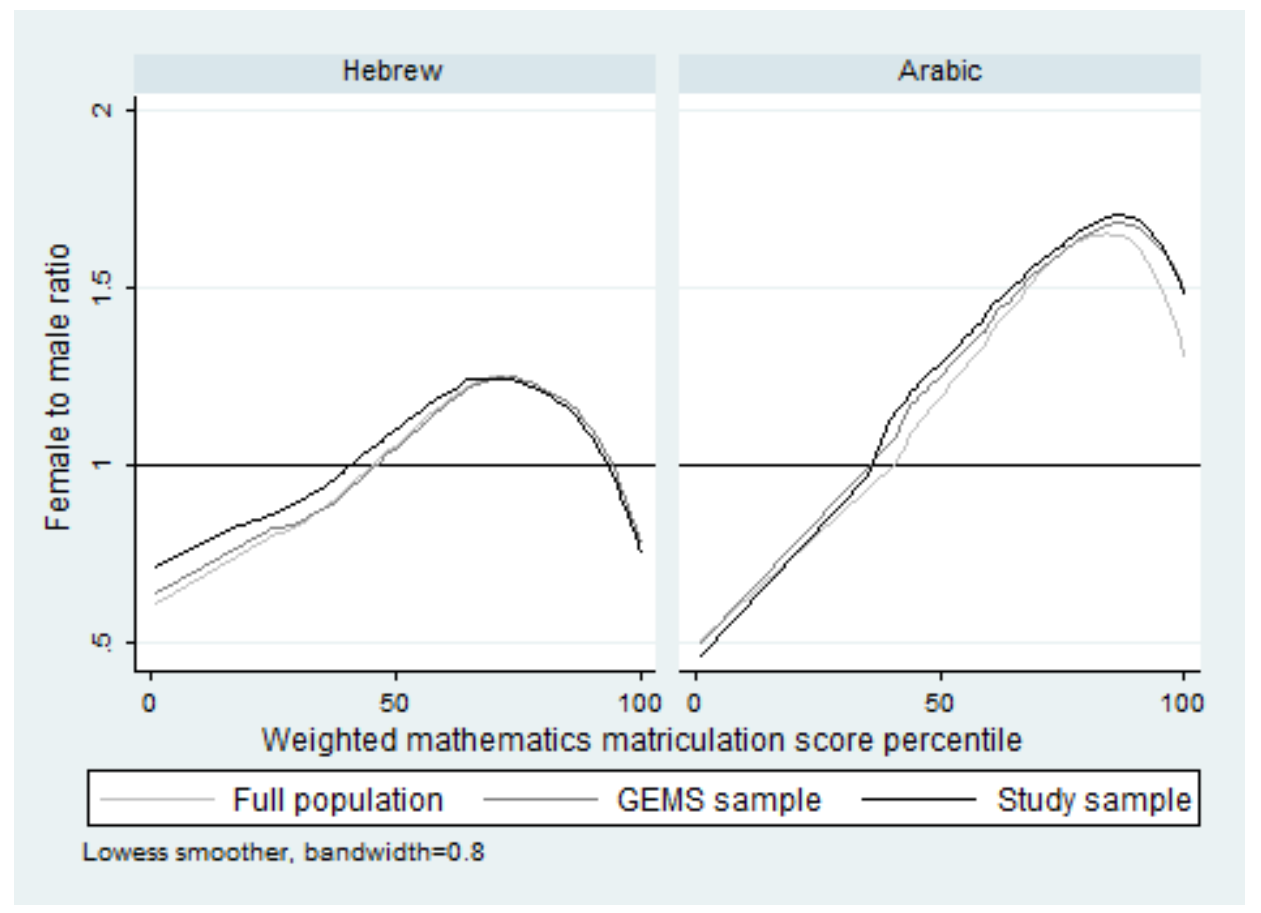

Matriculation mathematics exams are identical across language sectors, and students choose if to take the mathematics matriculation exam and the difficulty level of the test. To account for differences in the level of difficulty we construct a unified matriculation mathematics score that follows the weighting system used to determine university admissions in Israel-25 point bonus for 5 units, 15 point bonus for 4 units and no bonus for 3 units. For students taking 1 unit of mathematics (not enough for full matriculation, and therefore not enough to gain admission to university) we deduct 50 points (with a lower bound of 0 ); and we assign 0 points to students not taking any matriculation mathematics test. Students are then sorted into achievement percentiles, separately for Hebrew- and Arabic-language schools, in which the lowest percentile is relatively large, containing $28 \%$ of the full population, leaving empty the following percentiles. 
Table A2: Sample composition and attrition

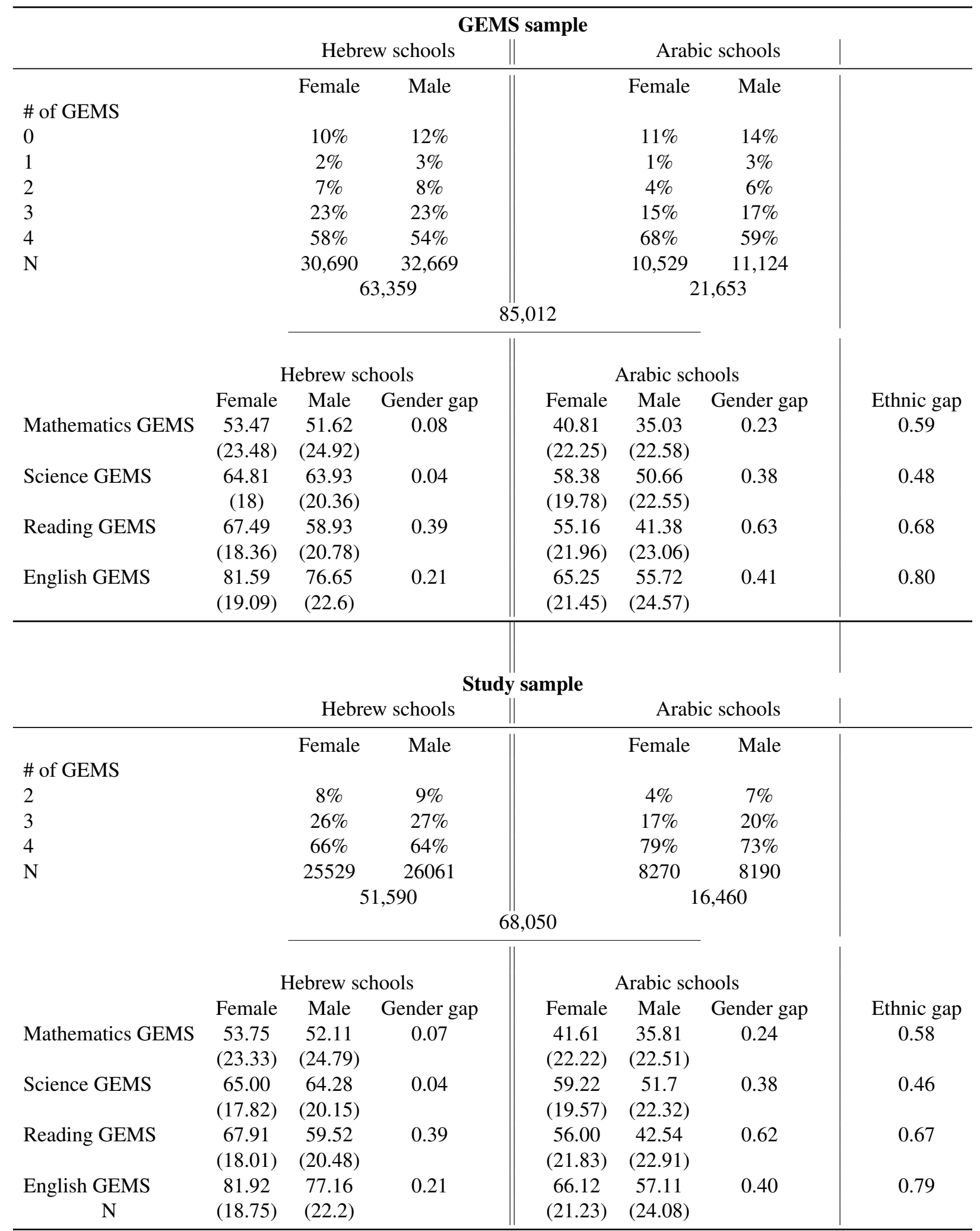

Gender gap $=($ female average-male average $) /$ sample standard deviation; ethnic gap= (Hebrew average-Arabic average)/sample standard deviation 


\section{A2 Regression outputs}

Table A3: Eighth-grade GEMS scores, conditioned on gender, ethnicity and socio-economic indicators

\begin{tabular}{|c|c|c|c|c|c|c|c|c|}
\hline \multirow[b]{2}{*}{ Female } & \multicolumn{2}{|c|}{ Mathematics } & \multicolumn{2}{|c|}{ Science } & \multicolumn{2}{|c|}{ Reading } & \multicolumn{2}{|c|}{ English } \\
\hline & $\begin{array}{l}0.07 * * * \\
(0.01)\end{array}$ & $\begin{array}{l}0.08^{* * * *} \\
(0.01)\end{array}$ & $\begin{array}{l}0.04 * * \\
(0.01)\end{array}$ & $\begin{array}{l}0.05^{* * * *} \\
(0.01)\end{array}$ & $\begin{array}{l}0.38^{* * * *} \\
(0.01)\end{array}$ & $\begin{array}{l}0.39 * * * \\
(0.01)\end{array}$ & $\begin{array}{l}0.20 * * * \\
(0.01)\end{array}$ & $\begin{array}{l}0.21 * * * \\
(0.01)\end{array}$ \\
\hline Arab & $\begin{array}{l}-0.66 * * * \\
(0.04)\end{array}$ & $\begin{array}{l}-0.27 * * * \\
(0.04)\end{array}$ & $\begin{array}{l}-0.62 * * * \\
(0.04)\end{array}$ & $\begin{array}{l}-0.27 * * * \\
(0.04)\end{array}$ & $\begin{array}{l}-0.77 * * * \\
(0.04)\end{array}$ & $\begin{array}{l}-0.43 * * * \\
(0.04)\end{array}$ & $\begin{array}{l}-0.86 * * * \\
(0.05)\end{array}$ & $\begin{array}{l}-0.46^{* * * *} \\
(0.05)\end{array}$ \\
\hline Female X Arab & $\begin{array}{l}0.17 * * * \\
(0.03)\end{array}$ & $\begin{array}{l}0.16^{* * * *} \\
(0.02)\end{array}$ & $\begin{array}{l}0.34 * * * \\
(0.03)\end{array}$ & $\begin{array}{l}0.33 * * * \\
(0.02)\end{array}$ & $\begin{array}{l}0.23 * * * \\
(0.02)\end{array}$ & $\begin{array}{l}0.23 * * * \\
(0.02)\end{array}$ & $\begin{array}{l}0.18^{* * * *} \\
(0.02)\end{array}$ & $\begin{array}{l}0.18 * * * \\
(0.02)\end{array}$ \\
\hline \multicolumn{9}{|c|}{ Family income quintiles } \\
\hline 2nd & & $\begin{array}{l}0.07 * * * \\
(0.02)\end{array}$ & & $\begin{array}{l}0.08 * * * \\
(0.01)\end{array}$ & & $\begin{array}{l}0.09 * * * \\
(0.01)\end{array}$ & & $\begin{array}{l}0.07 * * * \\
(0.01)\end{array}$ \\
\hline $3 \mathrm{rd}$ & & $\begin{array}{l}0.13^{* * * *} \\
(0.02)\end{array}$ & & $\begin{array}{l}0.14 * * * \\
(0.02)\end{array}$ & & $\begin{array}{l}0.14 * * * \\
(0.02)\end{array}$ & & $\begin{array}{l}0.13^{* * * *} \\
(0.02)\end{array}$ \\
\hline 4th & & $\begin{array}{l}0.24 * * * \\
(0.02)\end{array}$ & & $\begin{array}{l}0.25^{* * *} \\
(0.02)\end{array}$ & & $\begin{array}{l}0.26^{* * * *} \\
(0.02)\end{array}$ & & $\begin{array}{l}0.23 * * * \\
(0.02)\end{array}$ \\
\hline 5 th & & $\begin{array}{l}0.42 * * * \\
(0.02)\end{array}$ & & $\begin{array}{l}0.37 * * * \\
(0.02)\end{array}$ & & $\begin{array}{l}0.41 \text { *** } \\
(0.02)\end{array}$ & & $\begin{array}{l}0.40 * * * \\
(0.02)\end{array}$ \\
\hline Immigrant & & $\begin{array}{l}0.09 * * \\
(0.03)\end{array}$ & & $\begin{array}{l}-0.03 \\
(0.02)\end{array}$ & & $\begin{array}{l}-0.21 * * * \\
(0.02)\end{array}$ & & $\begin{array}{l}0.08 * * * \\
(0.02)\end{array}$ \\
\hline \multicolumn{9}{|c|}{ Parents' maximal years of schooling } \\
\hline 12 years & & $\begin{array}{l}0.24 * * * \\
(0.02)\end{array}$ & & $\begin{array}{l}0.26 * * * \\
(0.02)\end{array}$ & & $\begin{array}{l}0.29 * * * \\
(0.02)\end{array}$ & & $\begin{array}{l}0.28 * * * \\
(0.02)\end{array}$ \\
\hline $13-15$ years & & $\begin{array}{l}0.51 * * * \\
(0.02)\end{array}$ & & $\begin{array}{l}0.51 * * * \\
(0.02)\end{array}$ & & $\begin{array}{l}0.52 * * * \\
(0.02)\end{array}$ & & $\begin{array}{l}0.56^{* * * *} \\
(0.02)\end{array}$ \\
\hline 16 years or more & & $\begin{array}{l}0.67 * * * \\
(0.02)\end{array}$ & & $\begin{array}{l}0.63 * * * \\
(0.02)\end{array}$ & & $\begin{array}{l}0.66 \text { *** } \\
(0.02)\end{array}$ & & $\begin{array}{l}0.71 * * * \\
(0.02)\end{array}$ \\
\hline Constant & $\begin{array}{l}0.05 \\
(0.03)\end{array}$ & $\begin{array}{l}-0.56 * * * \\
(0.03)\end{array}$ & $\begin{array}{l}0.24 * * * \\
(0.02)\end{array}$ & $\begin{array}{l}-0.34 * * * \\
(0.03)\end{array}$ & $\begin{array}{l}-0.06^{*} \\
(0.02)\end{array}$ & $\begin{array}{l}-0.65 * * * \\
(0.03)\end{array}$ & $\begin{array}{l}-0.03 \\
(0.03)\end{array}$ & $\begin{array}{l}-0.67 * * * \\
(0.03)\end{array}$ \\
\hline Observations & 61,064 & 61,064 & 60,157 & 60,157 & 62,429 & 62,429 & 61,210 & 61,210 \\
\hline R-squared & 0.074 & 0.166 & 0.062 & 0.140 & 0.138 & 0.233 & 0.156 & 0.255 \\
\hline
\end{tabular}

Notes: Dependent variables vary by vertical panel, they are standardized GEMS scores. Coefficients are obtained from a linear regression model with school-level clustered standard errors and a dummy for cohort. Family SES variables include family income quintiles, parents' maximal years of schooling and immigrant status. Standard errors in parentheses.

$* p<0.05$ ** $p<0.01 \quad * * * \quad p<0.001$ 
Table A4: Propensity for twelfth-grade attainment, conditional on gender, ethnicity and socioeconomic indicators and prior achievement

\begin{tabular}{|c|c|c|c|c|c|c|}
\hline \multirow[b]{2}{*}{ Female } & \multicolumn{3}{|c|}{ Twelfth-grade retention } & \multicolumn{3}{|c|}{ Matriculation } \\
\hline & $\begin{array}{l}0.05^{* * * *} \\
(0.00)\end{array}$ & $\begin{array}{l}0.06 * * * \\
(0.00)\end{array}$ & $\begin{array}{l}0.04 * * * \\
(0.00)\end{array}$ & $\begin{array}{l}0.12 * * * \\
(0.01)\end{array}$ & $\begin{array}{l}0.13^{* * * *} \\
(0.01)\end{array}$ & $\begin{array}{l}0.07 * * * \\
(0.00)\end{array}$ \\
\hline Arab & $\begin{array}{l}-0.13 * * * \\
(0.03)\end{array}$ & $\begin{array}{l}-0.07 * * \\
(0.02)\end{array}$ & $\begin{array}{l}-0.02 \\
(0.02)\end{array}$ & $\begin{array}{l}-0.27 * * * \\
(0.02)\end{array}$ & $\begin{array}{l}-0.08 * * * \\
(0.02)\end{array}$ & $\begin{array}{l}0.01 \\
(0.01)\end{array}$ \\
\hline Female X Arab & $\begin{array}{l}0.11 * * * \\
(0.02)\end{array}$ & $\begin{array}{l}0.11 * * * \\
(0.02)\end{array}$ & $\begin{array}{l}0.07 * * * \\
(0.02)\end{array}$ & $\begin{array}{l}0.09 * * * \\
(0.01)\end{array}$ & $\begin{array}{l}0.09 * * * \\
(0.01)\end{array}$ & $\begin{array}{l}0.04 * * * \\
(0.01)\end{array}$ \\
\hline \multicolumn{7}{|l|}{ Family income quintiles } \\
\hline 2nd & & $\begin{array}{l}0.03 * * * \\
(0.01)\end{array}$ & $\begin{array}{l}0.02 * * * \\
(0.01)\end{array}$ & & $\begin{array}{l}0.04 * * * \\
(0.01)\end{array}$ & $\begin{array}{l}0.02 * * * \\
(0.01)\end{array}$ \\
\hline $3 \mathrm{rd}$ & & $\begin{array}{l}0.07 * * * \\
(0.01)\end{array}$ & $\begin{array}{l}0.05 * * * \\
(0.01)\end{array}$ & & $\begin{array}{l}0.09 * * * \\
(0.01)\end{array}$ & $\begin{array}{l}0.05 * * * \\
(0.01)\end{array}$ \\
\hline 4 th & & $\begin{array}{l}0.09 * * * \\
(0.01)\end{array}$ & $\begin{array}{l}0.06 * * * \\
(0.01)\end{array}$ & & $\begin{array}{l}0.16 * * * \\
(0.01)\end{array}$ & $\begin{array}{l}0.09 * * * \\
(0.01)\end{array}$ \\
\hline 5 th & & $\begin{array}{l}0.11 * * * \\
(0.01)\end{array}$ & $\begin{array}{l}0.07 * * * \\
(0.01)\end{array}$ & & $\begin{array}{l}0.25^{* * * *} \\
(0.01)\end{array}$ & $\begin{array}{l}0.14 * * * \\
(0.01)\end{array}$ \\
\hline Immigrant & & $\begin{array}{l}-0.06 * * * \\
(0.01)\end{array}$ & $\begin{array}{l}-0.05^{* * *} \\
(0.01)\end{array}$ & & $\begin{array}{l}-0.05 * * * \\
(0.01)\end{array}$ & $\begin{array}{l}-0.04 * * * \\
(0.01)\end{array}$ \\
\hline \multicolumn{7}{|c|}{ Parents' maximal years of schooling } \\
\hline 12 years & & $\begin{array}{l}0.07 * * * \\
(0.01)\end{array}$ & $\begin{array}{l}0.04 * * * \\
(0.01)\end{array}$ & & $\begin{array}{l}0.13 * * * \\
(0.01)\end{array}$ & $\begin{array}{l}0.06 * * * \\
(0.01)\end{array}$ \\
\hline $13-15$ years & & $\begin{array}{l}0.09 * * * \\
(0.01)\end{array}$ & $\begin{array}{l}0.04 * * * \\
(0.01)\end{array}$ & & $\begin{array}{l}0.25^{* * *} \\
(0.01)\end{array}$ & $\begin{array}{l}0.10^{* * * *} \\
(0.01)\end{array}$ \\
\hline 16 years or more & & $\begin{array}{l}0.09 * * * \\
(0.01)\end{array}$ & $\begin{array}{l}0.03 * * * \\
(0.01)\end{array}$ & & $\begin{array}{l}0.31 * * * \\
(0.01)\end{array}$ & $\begin{array}{l}0.12 * * * \\
(0.01)\end{array}$ \\
\hline \multicolumn{7}{|l|}{ GEMS } \\
\hline Mathematics & & & $\begin{array}{l}0.02 * * * \\
(0.00)\end{array}$ & & & $\begin{array}{l}0.09 * * * \\
(0.00)\end{array}$ \\
\hline Science & & & $\begin{array}{l}0.02 * * * \\
(0.00)\end{array}$ & & & $\begin{array}{l}0.04 * * * \\
(0.00)\end{array}$ \\
\hline Reading & & & $\begin{array}{l}0.03 * * * \\
(0.00)\end{array}$ & & & $\begin{array}{l}0.08 * * * \\
(0.00)\end{array}$ \\
\hline English & & & $\begin{array}{l}0.02 * * * \\
(0.00)\end{array}$ & & & $\begin{array}{l}0.05^{* * *} \\
(0.00)\end{array}$ \\
\hline Mathematics X Reading & & & $\begin{array}{l}-0.00 \\
(0.00)\end{array}$ & & & $\begin{array}{l}0.01 * \\
(0.00)\end{array}$ \\
\hline GEMS $^{2}$ & & & & & & \\
\hline Mathematics $^{2}$ & & & $\begin{array}{l}-0.00 * \\
(0.00)\end{array}$ & & & $\begin{array}{l}-0.01 * * * \\
(0.00)\end{array}$ \\
\hline Science $^{2}$ & & & $\begin{array}{l}-0.01 * * * \\
(0.00)\end{array}$ & & & $\begin{array}{l}0.01 * * \\
(0.00)\end{array}$ \\
\hline Reading $^{2}$ & & & $\begin{array}{l}-0.02 * * * \\
(0.00)\end{array}$ & & & $\begin{array}{l}0.00 \\
(0.00)\end{array}$ \\
\hline English $^{2}$ & & & $\begin{array}{l}-0.01 \\
(0.00)\end{array}$ & & & $\begin{array}{l}0.02 * * * \\
(0.00)\end{array}$ \\
\hline Constant & $\begin{array}{l}0.89 * * * \\
(0.01)\end{array}$ & $\begin{array}{l}0.76 * * * \\
(0.01)\end{array}$ & $\begin{array}{l}0.82 * * * \\
(0.01)\end{array}$ & $\begin{array}{l}0.55 * * * \\
(0.01)\end{array}$ & $\begin{array}{l}0.25 * * * \\
(0.01)\end{array}$ & $\begin{array}{l}0.40 * * * \\
(0.01)\end{array}$ \\
\hline R-squared & 0.035 & 0.073 & 0.142 & 0.059 & 0.158 & 0.321 \\
\hline
\end{tabular}

Notes: $N_{\text {total }}=68,050$. Dependent variables vary by vertical panel: twelfth-grade retention and matriculation rates. Coefficients are obtained from a LPM with school-level clustered standard errors and a dummy for cohort. All GEMS scores are normalized to have a mean of 0 and standard deviation of 1. Standard errors in parentheses. * $p<0.05 \quad * * p<0.01 \quad * * * p<0.001$ 
Table A5: Choice of advanced science and mathematics electives, conditional on gender, ethnicity, prior achievement and socio-economic status

\begin{tabular}{|c|c|c|c|c|c|c|c|c|c|c|c|c|}
\hline \multirow[b]{2}{*}{ Female } & \multicolumn{4}{|c|}{ Physics or computer science } & \multicolumn{4}{|c|}{ Advanced mathematics } & \multicolumn{4}{|c|}{ Biology or chemistry } \\
\hline & $\begin{array}{l}-0.11 * * * \\
(0.01)\end{array}$ & $\begin{array}{l}-0.10^{* * * *} \\
(0.01)\end{array}$ & $\begin{array}{l}-0.12 * * * * \\
(0.00)\end{array}$ & $\begin{array}{l}-0.12 * * * \\
(0.00)\end{array}$ & $\begin{array}{l}-0.02 * * * \\
(0.00)\end{array}$ & $\begin{array}{l}-0.02 * * * \\
(0.00)\end{array}$ & $\begin{array}{l}-0.04 * * * \\
(0.00)\end{array}$ & $\begin{array}{l}-0.04 * * * \\
(0.00)\end{array}$ & $\begin{array}{l}0.06 * * * \\
(0.01)\end{array}$ & $\begin{array}{l}0.07 * * * \\
(0.01)\end{array}$ & $\begin{array}{l}0.04 * * * \\
(0.01)\end{array}$ & $\begin{array}{l}0.04 * * * \\
(0.01)\end{array}$ \\
\hline Arab & $\begin{array}{l}-0.10 * * * \\
(0.01)\end{array}$ & $\begin{array}{l}-0.00 \\
(0.01)\end{array}$ & $\begin{array}{l}0.03 * * * \\
(0.01)\end{array}$ & $\begin{array}{l}0.02 \\
(0.05)\end{array}$ & $\begin{array}{l}-0.08 * * * \\
(0.01)\end{array}$ & $\begin{array}{l}0.03 * * \\
(0.01)\end{array}$ & $\begin{array}{l}0.07 * * * \\
(0.01)\end{array}$ & $\begin{array}{l}0.00 \\
(0.04)\end{array}$ & $\begin{array}{l}0.09 * * * \\
(0.02)\end{array}$ & $\begin{array}{l}0.19 * * * \\
(0.02)\end{array}$ & $\begin{array}{l}0.24 * * * \\
(0.02)\end{array}$ & $\begin{array}{l}0.05 \\
(0.03)\end{array}$ \\
\hline Female X Arab & $\begin{array}{l}0.12 * * * \\
(0.01)\end{array}$ & $\begin{array}{l}0.12 * * * \\
(0.01)\end{array}$ & $\begin{array}{l}0.10^{* * * *} \\
(0.01)\end{array}$ & $\begin{array}{l}0.10^{* * * *} \\
(0.01)\end{array}$ & $\begin{array}{l}0.06^{* * * *} \\
(0.01)\end{array}$ & $\begin{array}{l}0.05^{* * * *} \\
(0.01)\end{array}$ & $\begin{array}{l}0.04 * * * \\
(0.01)\end{array}$ & $\begin{array}{l}0.04 * * * \\
(0.01)\end{array}$ & $\begin{array}{l}0.12 \text { *** } \\
(0.01)\end{array}$ & $\begin{array}{l}0.12^{* * * *} \\
(0.01)\end{array}$ & $\begin{array}{l}0.09 * * * \\
(0.01)\end{array}$ & $\begin{array}{l}0.06 * * * \\
(0.01)\end{array}$ \\
\hline \multicolumn{13}{|c|}{ Family income quintiles } \\
\hline \multicolumn{2}{|c|}{ 2nd } & $\begin{array}{l}0.01 * * * \\
(0.00)\end{array}$ & $\begin{array}{l}0.01 * \\
(0.00)\end{array}$ & $\begin{array}{l}0.00 \\
(0.00)\end{array}$ & & $\begin{array}{l}0.01 * * * \\
(0.00)\end{array}$ & $\begin{array}{l}0.01 \\
(0.00)\end{array}$ & $\begin{array}{l}0.00 \\
(0.00)\end{array}$ & & $\begin{array}{l}0.03 * * * \\
(0.01)\end{array}$ & $\begin{array}{l}0.02 * * * * \\
(0.00)\end{array}$ & $\begin{array}{l}0.02 * * * \\
(0.00)\end{array}$ \\
\hline \multicolumn{2}{|l|}{$3 \mathrm{rd}$} & $\begin{array}{l}0.03 * * * \\
(0.00)\end{array}$ & $\begin{array}{l}0.01 * * * \\
(0.00)\end{array}$ & $\begin{array}{l}0.01 * \\
(0.00)\end{array}$ & & $\begin{array}{l}0.02 * * * \\
(0.00)\end{array}$ & $\begin{array}{l}0.01 * \\
(0.00)\end{array}$ & $\begin{array}{l}0.01 \\
(0.00)\end{array}$ & & $\begin{array}{l}0.04 * * * \\
(0.01)\end{array}$ & $\begin{array}{l}0.02 * * * \\
(0.01)\end{array}$ & $\begin{array}{l}0.02 \text { **** } \\
(0.00)\end{array}$ \\
\hline \multicolumn{2}{|l|}{ 4th } & $\begin{array}{l}0.05^{* * * *} \\
(0.00)\end{array}$ & $\begin{array}{l}0.02^{* * * *} \\
(0.00)\end{array}$ & $\begin{array}{l}0.02^{* * * *} \\
(0.00)\end{array}$ & & $\begin{array}{l}0.06 * * * * \\
(0.00)\end{array}$ & $\begin{array}{l}0.02 * * * \\
(0.00)\end{array}$ & $\begin{array}{l}0.02 * * * \\
(0.00)\end{array}$ & & $\begin{array}{l}0.07 * * * \\
(0.01)\end{array}$ & $\begin{array}{l}0.03^{* * * *} \\
(0.01)\end{array}$ & $\begin{array}{l}0.03 * * * \\
(0.00)\end{array}$ \\
\hline 5th & & $\begin{array}{l}0.11 * * * \\
(0.01)\end{array}$ & $\begin{array}{l}0.05^{* * * *} \\
(0.01)\end{array}$ & $\begin{array}{l}0.05^{* * * *} \\
(0.01)\end{array}$ & & $\begin{array}{l}0.13 * * * \\
(0.01)\end{array}$ & $\begin{array}{l}0.05 * * * \\
(0.00)\end{array}$ & $\begin{array}{l}0.05 * * * \\
(0.00)\end{array}$ & & $\begin{array}{l}0.10^{* * * *} \\
(0.01)\end{array}$ & $\begin{array}{l}0.03^{* * *} \\
(0.01)\end{array}$ & $\begin{array}{l}0.03 * * * \\
(0.01)\end{array}$ \\
\hline \multicolumn{2}{|l|}{ Immigrant } & $\begin{array}{l}0.03^{* * * *} \\
(0.01)\end{array}$ & $\begin{array}{l}0.03^{* * * *} \\
(0.00)\end{array}$ & $\begin{array}{l}0.02 * * * \\
(0.00)\end{array}$ & & $\begin{array}{l}0.03 * * * \\
(0.01)\end{array}$ & $\begin{array}{l}0.02 * * * \\
(0.01)\end{array}$ & $\begin{array}{l}0.02 * * * \\
(0.00)\end{array}$ & & $\begin{array}{l}0.02 * * \\
(0.01)\end{array}$ & $\begin{array}{l}0.02 * * * \\
(0.01)\end{array}$ & $\begin{array}{l}0.03 * * * * \\
(0.00)\end{array}$ \\
\hline \multicolumn{13}{|c|}{ Parents' maximal years of schooling } \\
\hline \multicolumn{2}{|c|}{12 years } & $\begin{array}{l}0.04 * * * \\
(0.00)\end{array}$ & $\begin{array}{l}0.01 * * * \\
(0.00)\end{array}$ & $\begin{array}{l}0.01 * * \\
(0.00)\end{array}$ & & $\begin{array}{l}0.05 * * * \\
(0.00)\end{array}$ & $\begin{array}{l}0.02 * * * \\
(0.00)\end{array}$ & $\begin{array}{l}0.01 * * \\
(0.00)\end{array}$ & & $\begin{array}{l}0.08 * * * \\
(0.01)\end{array}$ & $\begin{array}{l}0.04 * * * \\
(0.01)\end{array}$ & $\begin{array}{l}0.03 * * * \\
(0.01)\end{array}$ \\
\hline \multicolumn{2}{|l|}{$13-15$ years } & $\begin{array}{l}0.10^{* * * *} \\
(0.01)\end{array}$ & $\begin{array}{l}0.04 * * * \\
(0.00)\end{array}$ & $\begin{array}{l}0.03^{* * * *} \\
(0.00)\end{array}$ & & $\begin{array}{l}0.12 * * * \\
(0.01)\end{array}$ & $\begin{array}{l}0.04 * * * \\
(0.01)\end{array}$ & $\begin{array}{l}0.03 * * * \\
(0.00)\end{array}$ & & $\begin{array}{l}0.14 * * * \\
(0.01)\end{array}$ & $\begin{array}{l}0.06 * * * \\
(0.01)\end{array}$ & $\begin{array}{l}0.05^{* * * *} \\
(0.01)\end{array}$ \\
\hline \multicolumn{2}{|l|}{16 years or more } & $\begin{array}{l}0.16^{* * * *} \\
(0.01)\end{array}$ & $\begin{array}{l}0.06^{* * * *} \\
(0.01)\end{array}$ & $\begin{array}{l}0.06^{* * * *} \\
(0.00)\end{array}$ & & $\begin{array}{l}0.21 * * * \\
(0.01)\end{array}$ & $\begin{array}{l}0.09 * * * \\
(0.01)\end{array}$ & $\begin{array}{l}0.08 * * * \\
(0.01)\end{array}$ & & $\begin{array}{l}0.18^{* * * *} \\
(0.01)\end{array}$ & $\begin{array}{l}0.08 * * * \\
(0.01)\end{array}$ & $\begin{array}{l}0.07 * * * \\
(0.01)\end{array}$ \\
\hline \multicolumn{13}{|l|}{ GEMS } \\
\hline \multicolumn{3}{|l|}{ Mathematics } & $\begin{array}{l}0.07 * * * \\
(0.00)\end{array}$ & $\begin{array}{l}0.07 * * * \\
(0.00)\end{array}$ & & & $\begin{array}{l}0.09 * * * \\
(0.00)\end{array}$ & $\begin{array}{l}0.10^{* * * *} \\
(0.00)\end{array}$ & & & $\begin{array}{l}0.05^{* * * *} \\
(0.00)\end{array}$ & $\begin{array}{l}0.05 * * * \\
(0.00)\end{array}$ \\
\hline \multicolumn{3}{|l|}{ Science } & $\begin{array}{l}0.03 * * * \\
(0.00)\end{array}$ & $\begin{array}{l}0.02 * * * \\
(0.00)\end{array}$ & & & $\begin{array}{l}0.03 * * * \\
(0.00)\end{array}$ & $\begin{array}{l}0.03 * * * \\
(0.00)\end{array}$ & & & $\begin{array}{l}0.04 * * * \\
(0.00)\end{array}$ & $\begin{array}{l}0.04 * * * * \\
(0.00)\end{array}$ \\
\hline \multicolumn{3}{|l|}{ Reading } & $\begin{array}{l}0.03^{* * * *} \\
(0.00)\end{array}$ & $\begin{array}{l}0.02 * * * \\
(0.00)\end{array}$ & & & $\begin{array}{l}0.03 * * * \\
(0.00)\end{array}$ & $\begin{array}{l}0.03 * * * \\
(0.00)\end{array}$ & & & $\begin{array}{l}0.05^{* * * *} \\
(0.00)\end{array}$ & $\begin{array}{l}0.04 * * * \\
(0.00)\end{array}$ \\
\hline \multicolumn{3}{|l|}{ English } & $\begin{array}{l}0.02 * * * \\
(0.00)\end{array}$ & $\begin{array}{l}0.02 * * * \\
(0.00)\end{array}$ & & & $\begin{array}{l}0.02 * * * \\
(0.00)\end{array}$ & $\begin{array}{l}0.02 * * * \\
(0.00)\end{array}$ & & & $\begin{array}{l}0.01 * * * \\
(0.00)\end{array}$ & $\begin{array}{l}0.01 * * * \\
(0.00)\end{array}$ \\
\hline \multicolumn{3}{|c|}{ Mathematics X Reading } & $\begin{array}{l}0.01 * * * \\
(0.00)\end{array}$ & $\begin{array}{l}0.01 * * * \\
(0.00)\end{array}$ & & & $\begin{array}{l}0.02 * * * \\
(0.00)\end{array}$ & $\begin{array}{l}0.02 * * * \\
(0.00)\end{array}$ & & & $\begin{array}{l}0.01 * * \\
(0.00)\end{array}$ & $\begin{array}{l}0.01 * \\
(0.00)\end{array}$ \\
\hline \multicolumn{13}{|l|}{ GEMSर̂ } \\
\hline \multicolumn{2}{|l|}{ Mathematics } & & $\begin{array}{l}0.05 * * * \\
(0.00)\end{array}$ & $\begin{array}{l}0.05^{* * * *} \\
(0.00)\end{array}$ & & & $\begin{array}{l}0.07 * * * \\
(0.00)\end{array}$ & $\begin{array}{l}0.07 * * * \\
(0.00)\end{array}$ & & & $\begin{array}{l}0.00 \\
(0.00)\end{array}$ & $\begin{array}{l}0.00 \\
(0.00)\end{array}$ \\
\hline \multicolumn{2}{|l|}{ Science } & & $\begin{array}{l}0.02 * * * \\
(0.00)\end{array}$ & $\begin{array}{l}0.02 * * * \\
(0.00)\end{array}$ & & & $\begin{array}{l}0.02 * * * \\
(0.00)\end{array}$ & $\begin{array}{l}0.02 * * * \\
(0.00)\end{array}$ & & & $\begin{array}{l}0.02 * * * \\
(0.00)\end{array}$ & $\begin{array}{l}0.02 * * * \\
(0.00)\end{array}$ \\
\hline \multicolumn{2}{|l|}{ Reading } & & $\begin{array}{l}0.00^{*} \\
(0.00)\end{array}$ & $\begin{array}{l}0.00 \\
(0.00)\end{array}$ & & & $\begin{array}{l}0.01 * * * \\
(0.00)\end{array}$ & $\begin{array}{l}0.01 * * * \\
(0.00)\end{array}$ & & & $\begin{array}{l}-0.00 \\
(0.00)\end{array}$ & $\begin{array}{l}0.00 \\
(0.00)\end{array}$ \\
\hline English & & & $\begin{array}{l}0.01 * * * \\
(0.00)\end{array}$ & $\begin{array}{l}0.01 * * * \\
(0.00)\end{array}$ & & & $\begin{array}{l}0.00 * * \\
(0.00)\end{array}$ & $\begin{array}{l}0.01 * * * \\
(0.00)\end{array}$ & & & $\begin{array}{l}0.00^{*} \\
(0.00)\end{array}$ & $\begin{array}{l}0.00^{* * *} \\
(0.00)\end{array}$ \\
\hline \multicolumn{13}{|c|}{ School fixed-effects } \\
\hline Constant & $\begin{array}{l}0.17 * * * \\
(0.01)\end{array}$ & $\begin{array}{l}0.04 * * * \\
(0.01)\end{array}$ & $\begin{array}{l}0.11^{* * *} \\
(0.01)\end{array}$ & $\begin{array}{l}0.12 * * * \\
(0.01)\end{array}$ & $\begin{array}{l}0.16^{* * * *} \\
(0.01)\end{array}$ & $\begin{array}{l}0.00 \\
(0.01)\end{array}$ & $\begin{array}{l}0.09 \text { *** } \\
(0.01)\end{array}$ & $\begin{array}{l}0.12 \text { *** } \\
(0.01)\end{array}$ & $\begin{array}{l}0.13 * * * \\
(0.01)\end{array}$ & $\begin{array}{l}-0.04 * * * \\
(0.01)\end{array}$ & $\begin{array}{l}0.04 * * * \\
(0.01)\end{array}$ & $\begin{array}{l}0.10^{* * * *} \\
(0.01)\end{array}$ \\
\hline$R^{2}$ & 0.023 & 0.081 & 0.235 & 0.207 & 0.005 & 0.084 & 0.306 & 0.277 & 0.046 & 0.081 & 0.164 & 0.102 \\
\hline
\end{tabular}

Notes: $N_{\text {total }}=68,050$. Dependent variables vary by vertical panel: taking physics or computer science; advanced mathematics; and biology or chemistry. Coefficients are obtained from a LPM with school-level clustered standard errors and a dummy for cohort. All GEMS scores are normalized to have a mean of 0 and standard deviation of 1 . Standard errors in parentheses. ${ }^{*} p<0.05$ $* * p<0.01 \quad * * * p<0.001$ 